\title{
Seasonal-Dial Shifts of Ichthyoplankton Assemblages and Plastic Debris around an Equatorial Atlantic Archipelago
}

\author{
André R. A. Lima, Mario Barletta * and Monica F. Costa \\ Laboratório de Ecologia e Gerenciamento de Ecossistemas Costeiros e Estuarinos, Departamento de Oceanografia, \\ Universidade Federal de Pernambuco, Recife, Brazil
}

\section{OPEN ACCESS}

Edited by:

Maria Cristina Fossi,

University of Siena, Italy

Reviewed by:

Christos loakeimidis,

United Nations Environment

Programme, Mediterranean Action

Plan, Greece

Francois Galgani,

French Research Institute for Exploitation of the Sea, France

*Correspondence: Mario Barletta barletta@ufpe.br

Specialty section: This article was submitted to Marine Pollution,

a section of the journal Frontiers in Environmental Science

Received: 28 March 2016 Accepted: 15 August 2016 Published: 30 August 2016

Citation: Lima ARA, Barletta M and Costa MF (2016) Seasonal-Dial Shifts of Ichthyoplankton Assemblages and Plastic Debris around an Equatorial Atlantic Archipelago.

Front. Environ. Sci. 4:56. doi: 10.3389/fenvs.2016.00056
Seasonality was a stronger influence in the ichthyoplankton assemblages around the Saint Peter and Saint Paul Archipelago (SPSPA) than distance from the islands. Plastic debris were ubiquitous and although it presented diel trends, no other spatiotemporal patterns was showed. Larval Oxyporhamphus micropterus was the most important taxa (29.37\% of the total catch), followed by Ceratoscopelus warmingii and Entomacrodus vomerianus. Exocoetidae eggs represented $41.01 \%$. Mesopelagic fish larvae dominated the community. Myctophidae had the highest species richness (15). Four larval fish assemblages occurred: (1) night-time demersal/bathydemersal (Anguillidae, Congridae); (2) daytime mesopelagic/bathypelagic/epipelagic (Myctophidae, Cyclothone acclinidens); (3) daytime epipelagic (Exocoetidae, Coryphaena hippurus, Thunnus albacares); and (4) night-time reef and demersal (Blennidae, Pomacentridae, Lutjanidae). The dry season (lower temperature, higher chlorophyll a and higher SW wind velocity) influenced the first two assemblages. The rainy season (higher temperatures and lower NW wind velocity) influenced the last two. Nighttime abundance of dominant species in the rainy season suggests diel vertical migration nearshore. Plastics were 2.12 times more abundant than the most abundant fish larvae. Comparable amounts of larvae and plastics in the water column increase the chances of interaction between these two compartments and might disturb the local marine food web and promote the transfer of microplastic from one habitat to another, especially when smaller taxa contaminated by ingested fragments are preyed by migratory animals such as marine birds and tuna. A study around the area concluded that at least a part of the plastic debris can have local source due to fishing activities. Small-scale oceanographic mechanisms such as the interaction between the topography and currents (SEC and EUC) seem to be responsible for the retention of fish eggs, fish larvae and plastics around SPSPA.

Keywords: fish larvae, remote oceanic island, marine debris, microplastics, Saint Peter and Saint Paul Archipelago

\section{INTRODUCTION}

Most marine fishes possess a pelagic larval phase, which disperse by drifting in ocean currents away from their spawning sites to areas of potential recruitment, where they might complete their life cycle (Pearce and Hutchins, 2009). However, larvae of some species are able to remain near adult habitat by mechanisms that evolved to avoid dispersal or advection to unfavorable areas 
(Boehlert et al., 1992; Vigliola et al., 1998; Sabatés et al., 2003; Moyano et al., 2014). Around oceanic islands these mechanisms include "winter cascading" (Boden and Kampa, 1953), retention in island eddies (Sale, 1970; Emery, 1972), flow-topography interactions (Hamner and Hauri, 1981; Wolanski and Hamner, 1988) and behavioral patterns such as ontogenetic migration (Leis and Trnski, 1989). Although self-recruitment is the main factor supporting local fish populations, larval inputs from other areas may also be important for the maintenance of these communities (Swearer et al., 1999; Cowen et al., 2006).

Oceanic islands and seamounts are important grounds for demersal and pelagic fishes in the open ocean, as well as hotspots for pelagic migratory species (e.g., genus Thunnus) (Boehlert and Mundy, 1993; Morato et al., 2010). Remote islands may be sites of higher (above average) primary productivity and zooplankton abundance when compared to the surrounding open ocean (Boehlert and Mundy, 1993; Macedo-Soares et al., 2009). They provide habitats in which larvae of pelagic and resident species can survive and grow (Dower and Perry, 2001). In these areas, the formation of fish assemblages is influenced by particular seasonal and spatial spawning patterns of adults (i.e., optimal physical and biotic conditions). Maintenance of these larval fish assemblages depends on larval behavior (i.e., seeking specific environmental features, prey search, directional swimming abilities), including the philopatry (tendency to return to natal home) and evolved local adaptation (Boehlert and Mundy, 1993; Bernardi, 2013).

Spatial scales are important to analyse changes in the structure and distribution of larval fish assemblages around oceanic islands (Boehlert and Mundy, 1993; Macedo-Soares et al., 2012), where fish larvae have been classed in four assemblage types: embayment areas, nearshore, intermediate nearshore or neritic and offshore, or oceanic (Boehlert and Mundy, 1993). This general pattern provide a greater understanding of habitats use by fish larvae around these islands.

Saint Peter and Saint Paul Archipelago (SPSPA) is a remote small group of rocky islands that rises few meters above sea level at the Mid-Atlantic Ridge. It represents a hotspot of biodiversity due to the concentration of pelagic fishes and high endemism of reef fishes (Vaske et al., 2005; Macedo-Soares et al., 2012). The local system of currents promotes vertical mixing between water masses and is likely to be the responsible for the formation, maintenance and disruption of the assemblages at the archipelago (Travassos et al., 1999). SPSPA is the main source of eggs and larvae that contribute to the formation of larval fish assemblages in the surrounding waters.

Most studies of plankton assemblages take in consideration only the living portion of this environmental compartment, leaving behind the non-living portion (Lima et al., 2014). The ubiquity of plastics pollution in the marine environment became a global concern (Costa and Barletta, 2015). Numerous studies have emerged in the last decades to elucidate the problems caused by the presence of plastic debris in the marine environment (Barnes et al., 2009; Thompson et al., 2009; Enders et al., 2015; Lusher et al., 2015; Yu et al., 2016). Plastic ingestion by marine fauna has been widely reported (Lusher, 2015). From these, $\sim 27 \%$ are related to fishes (Dantas et al., 2012; Ramos et al., 2012; Lusher, 2015; Neves et al., 2015; Sá et al., 2015; Ferreira et al.,
2016; Rummel et al., 2016) and 2\% to invertebrates (Besseling et al., 2014; Chua et al., 2014; Setälä et al., 2014, 2016; Lusher, 2015). Plastic debris that reach the sea originate mainly on land, through poor disposal practices such as accidental release, natural disasters and inadequate disposal habits (Thompson et al., 2009; Watters et al., 2010). Transport by rivers and winds permits entire plastic items and debris to enter the marine environment and travel over long distances along which they transform both physical and chemically (Wright et al., 2013).

In the marine environments, plastic fragments into microplastics $(<5 \mathrm{~mm})$. Great attention has been given to this size class of pollutant, as a fraction much more abundant and ubiquitous in the marine environment in terms of number of items, which occurs from mangrove creeks and estuaries to remote oceanic islands (Ivar do Sul et al., 2013; Lima et al., 2014, 2016). These fragments are likely to be the most hazardous to marine biota owing to their small size, physical harm, blockage, starvation and chemical contamination due to organic and inorganic pollutants absorbed by the ingested microplastic (Frias et al., 2010; Turner, 2010; Cole et al., 2011; Rochman et al., 2013; Tanaka et al., 2013; Lönnstedt and Eklöv, 2016; Wardrop et al., 2016).

Studies conducted around oceanic islands such as Fernando de Noronha, Abrolhos, Trindade (Western Atlantic) and SPSPA (Equatorial Atlantic), confirmed that pelagic microplastic pollution is widespread throughout the western tropical Atlantic Ocean (Ivar do Sul et al., 2013, 2014; Eriksen et al., 2014). This study describes the spatial, seasonal and daily distribution of ichthyoplankton assemblages and plastic debris according to their distance from SPSPA $(<100 \mathrm{~m},>100-500 \mathrm{~m}$ and $>500-$ $1500 \mathrm{~m}$ ) in order to assess how oceanographic factors might influence distribution patterns. Additionally, this study also describes the possible effects of the presence of microplastics together with larval fish assemblages around the study area.

\section{MATERIALS AND METHODS}

\section{Study Area}

The study area comprises the adjacent waters around the SPSPA $\left(0^{\circ} 55^{\prime} 01^{\prime \prime} \mathrm{N}, 29^{\circ} 20^{\prime} 44^{\prime \prime} \mathrm{W}\right)$, a group of 10 small islets and rocky summits that originated from a Meso-Atlantic elevation (plutonic massif with sedimentary covering) at $4000 \mathrm{~m}$ deep (Figure 1; Sichel et al., 2008). It is located in the Equatorial Atlantic Ocean at $1000 \mathrm{~km}$ from the northeastern cost of Brazil and $1800 \mathrm{~km}$ from the African coast. This archipelago is the smallest and most isolated archipelago in the Brazilian Exclusive Economic Zone, covering an area of $16,000 \mathrm{~m}^{2}$ (Macedo-Soares et al., 2012). The four major islets (Barão de Teffé, Saint Peter, Saint Paul, and Belmonte) form a small and shallow bay with depths from 4 to $25 \mathrm{~m}$. Reef habitats consist of nearly vertical cliffs extending almost $60 \mathrm{~m}$ deep. In the sublittoral zone a soft coral (Palythoa caribeorum), two hermatipic corals (Madracis decatis and Scolymia wellsi), two black corals (genus Antipathes) and 14 algae species (e.g., Caulerpa racemosa) are important producers of this system (Edwards and Lubbock, 1983; Amaral et al., 2009).

The main surface current of the archipelago is the South Equatorial Current (SEC) flowing westward. Its northern branch 

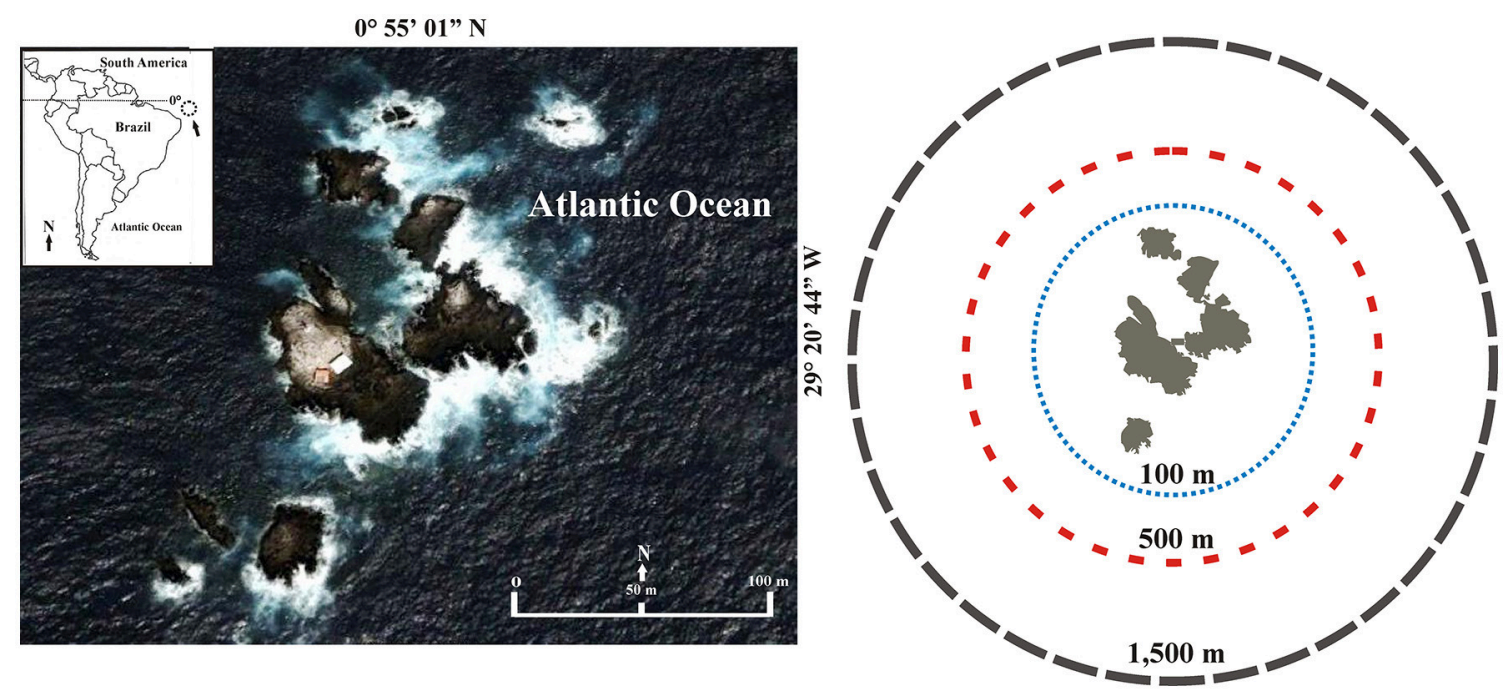

FIGURE 1 | Saint Peter and Saint Paul Archipelago. Distances from the Archipelago: D1, <100 m; D2, > 100-500 m; and D3, >500-1500 m. Source: Google Earth (2016) ${ }^{1}$.

reaches the archipelago at speeds between 0.2 and $0.4 \mathrm{~m} \mathrm{~s}^{-1}$ (Lumpkin and Garzoli, 2005). Flowing eastward at depths between 40 and $150 \mathrm{~m}$ is the Equatorial Undercurrent (EUC) (core speed: $0.7 \mathrm{~m} \mathrm{~s}^{-1}$ and edge speed: $0.1 \mathrm{~m} \mathrm{~s}^{-1}$ ) (Stramma and Schott, 1999). Southeast trade winds have a constant strength of $7 \mathrm{~m} \mathrm{~s}^{-1}$ (Soares et al., 2009). From January to May the archipelago is under the influence of the Intertropical Convergence Zone (ITCZ), which increases precipitation and triggers the rainy season (Macedo-Soares et al., 2012). In June, there is a northward movement of the ITCZ and the precipitation decreases, starting the dry season (Macedo-Soares et al., 2012).

\section{Sampling Methods}

Samples were conducted in the adjacent waters around the SPSPA in April, August and November 2003 and in March 2004. Samples were collected with a cylindrical-conical plankton net $(300 \mu \mathrm{m} ; \varnothing 0.6 \mathrm{~m} ; 2 \mathrm{~m}$ long) during $5-10 \mathrm{~min}$ at 2 knots. Subsurface plankton tows $(0-0.6 \mathrm{~m})$ were conducted during each month at three distances from the archipelago: $<100 \mathrm{~m}$ (D1), $>100-500 \mathrm{~m}$ (D2), and $>500-1500 \mathrm{~m}$ (D3). Three samples were collected during dusk and night (18:00-22:15 h) and three during dawn and morning (06:30-12:00 h) for each distance, a total of 72 horizontal subsurface tows. The volume filtered per tow was calculated using a flowmeter (General Oceanics - Model 2030 Digital Series). A GPS (Ensign GPS Trimble Navigation) determined the sampling position. Water temperature $\left({ }^{\circ} \mathrm{C}\right)$ and salinity (WTW LF 197) were recorded before the beginning of each sampling. Chlorophyll $a(\mathrm{Chl} a)$ values were obtained from the literature (Macedo-Soares et al., 2012). Wind velocity, wind direction and precipitation were obtained from the nearest

\footnotetext{
${ }^{1}$ https://www.google.com.br/maps/place/Arquip\%C3\%A9lago+de+S\%C3\%A3o+ Pedro+e+S\%C3\%A3o+Paulo/@0.9206109,-33.8352283,1570808m/data=!3m2!1e3! 4b1!4m5!3m4!1s0x89f2604fb4eb7e5:0x3c7e0c0b7f3267e3!8m2!3d0.916944!4d-29. 334444 (Accessed August 18, 2016).
}

oceanic mooring $\left(0^{\circ}, 35^{\circ} \mathrm{W}\right)$ (http://www.pmel.noaa.gov/pirata/) (Ivar do Sul et al., 2013). There are two main hydrological seasons at the archipelago: high $(300 \mathrm{~mm})$ and low $(10 \mathrm{~mm})$ monthly total precipitation. Samples were preserved in buffered formalin (4\%).

\section{Laboratory Procedures}

Samples were divided into smaller aliquots $(100 \mathrm{ml})$ to facilitate the separation of ichthyoplankton with the aid of a stereomicroscope-ZEISS; STEMI 2000-C (x5). Fish larvae and fish eggs were totally separated from the bulk sample and their counts per unit were converted to a standard volume of $100 \mathrm{~m}^{3}$. Ichthyoplankton were identified to the lowest possible taxonomic level identification following Fahay (1983), Moser (1996), Bonecker and Castro (2006) and Richards (2006). The classification of species habitat and mode of spawning followed Richards (2006) and Froese and Pauly (2015). The remaining plankton samples were filtered $(0.45 \mu \mathrm{m}$ filter $)$ and freeze-dried (Ivar do Sul et al., 2013). Plastic items were visually counted using a binocular stereomicroscope and classified into hard plastics, soft plastics, rubber crumbs, paint chips or threads. Color diversification was observed, registering blue, black, white, yellow, green, gray, red, brown and purple fragments (Ivar do Sul et al., 2013). These fragments were further divided into microplastics (range: $0.15-4.8 \mathrm{~mm}$; average $1.67 \pm 1.22 \mathrm{~mm}$ ) and larger items (range: 6.03-23.46; average: $13.94 \pm 5.11 \mathrm{~mm}$ ).

\section{Statistical Analysis}

Three subsurface water samples per period of the day (day and night $)$ in each distance $(<100 \mathrm{~m},>100-500 \mathrm{~m}$, and $>500$ $1500 \mathrm{~m}$ ) and month (April, August and November 2003 and March 2004) were considered as replicates, and were used to test the proposed hypothesis. The factorial analysis of variance (three-way ANOVA), with a 5\% level of significance, was performed to assess whether the distribution and density of the 
ichthyoplankton and plastics varied with space (D1, D2, D3), season (dry and rainy seasons) and between day and night (Zar, 1996). The Cochran's test was used to check the homogeneity of variances. The original data were Box-Cox transformed (Box and Cox, 1964) to increase normality of the distribution. The Bonferroni's test $(\alpha=0.05)$ was used whenever significant differences were detected (Quinn and Keough, 2002).

A canonical correspondence analysis (CCA) (CANOCO for Windows 4.5) was performed to detect ecological correlations (ter Braak and Smilauer, 2002). A multiple least-squares regression was computed with the site scores (derived from weighted averages of fish larvae, fish eggs, and plastic debris) as dependent variables and the environmental parameters (rainfall, water temperature, salinity, Chlorophyll $a$, wind velocity, and wind direction) as independent variables (ter Braak, 1986; Palmer, 1993). To avoid the effect of high density values, data were $\log _{10}(\mathrm{x}+1)$-transformed. The CCA was run with 100 iterations with randomized site locations to facilitate the MonteCarlo tests between the eigenvalues and species-environment correlations for each axis that resulted from CCA as well as those expected by chance. With this procedure, a triplot is produced where the environmental variables appear as vectors radiating from the origin of the ordination. The length of the vector is related to the power relationship between the environmental variable that the vector represents and the groups, for each main season.

\section{RESULTS}

\section{Oceanographic Variables}

Environmental measurements revealed two main periods: a warmer rainy period (March and April) and a colder dry period (August and November) (Figure 2). Although low average chlorophyll $a$ was observed in the warmer period, the highest average chlorophyll $a$ was observed in August and the lowest in November (Figure 2). Precipitation varied from $350 \mathrm{~mm}$ in April to $10 \mathrm{~mm}$ in November. Sea surface temperature was higher in March $\left(28^{\circ} \mathrm{C}\right)$ than in August and November (below $27^{\circ} \mathrm{C}$ ). However, in April, average water temperature was higher at $1500 \mathrm{~m}\left(27.8^{\circ} \mathrm{C}\right.$ ) than nearshore (below 27 ${ }^{\circ} \mathrm{C}$ ) (Figure 2). Average salinity was also higher in March (above 38) when compared to the other months (36 in April to 37 in November) (Figure 2).

\section{Composition, Abundance, and Structure of the Ichthyoplankton Assemblages and Plastic Debris}

In total, 1598 fish larvae (0.015 ind. $100 \mathrm{~m}^{-3}$ ) and 32,462 fish eggs (0.54 ind. $100 \mathrm{~m}^{-3}$ ) were collected, among which 55 taxa were identified as belonging to 24 families (Table 1). From these, 18 taxa were captured only during the rainy period and 7 taxa during the dry period. The ichthyoplankton was dominated by mesopelagic fish species (especially Myctophidae). The highest abundance was observed for the epipelagic flying fish Oxyporhamphus micropterus at 0.0044 ind. $100 \mathrm{~m}^{-3}(29.37 \%$ of the total catch). The mesopelagic lanternfish Ceratoscopelus
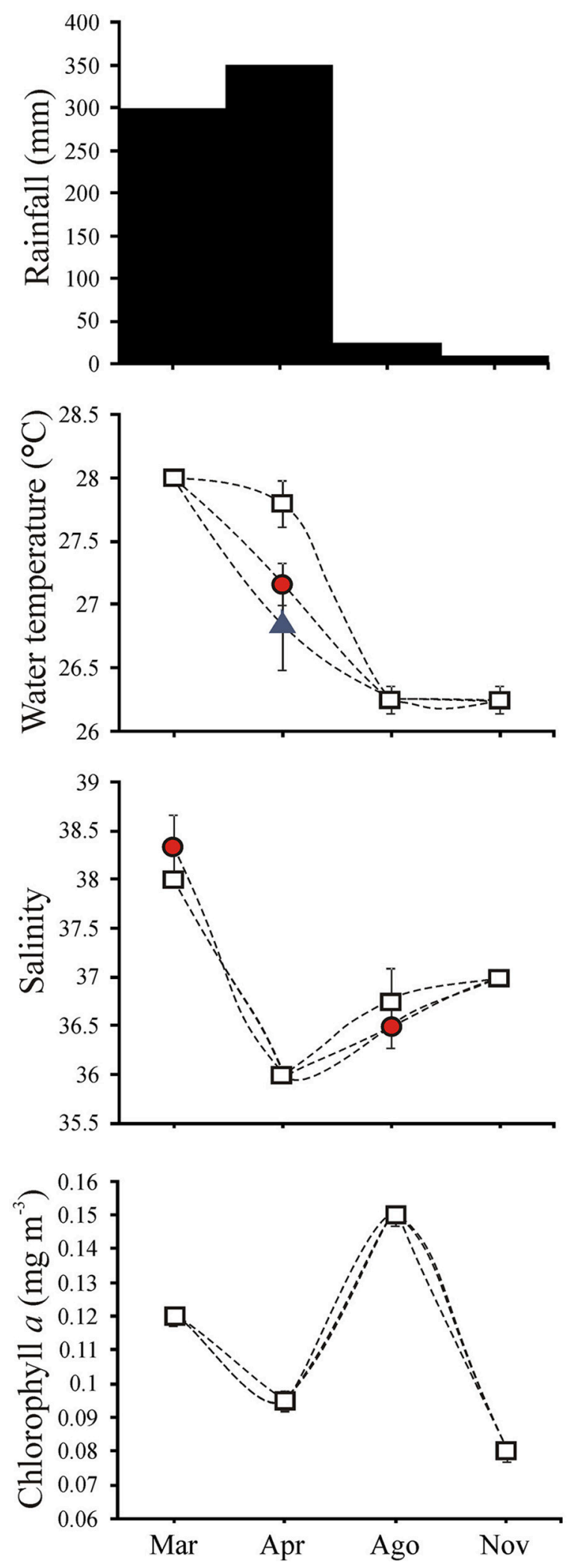

FIGURE 2 | Monthly total rainfall and water temperature $\left({ }^{\circ} \mathrm{C}\right)$, salinity

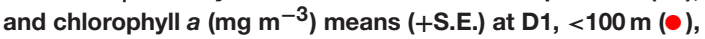

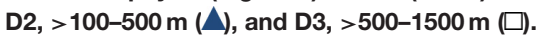




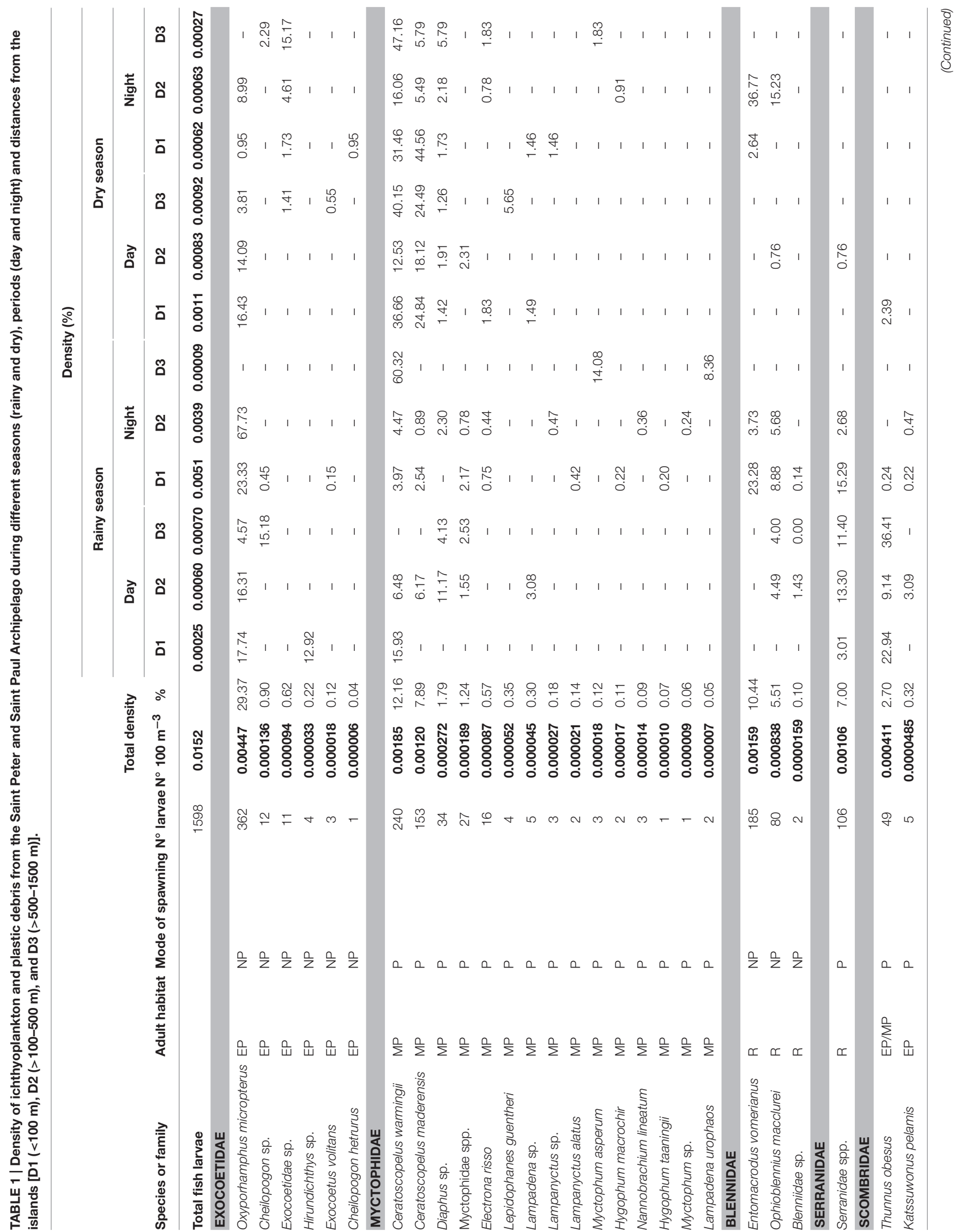




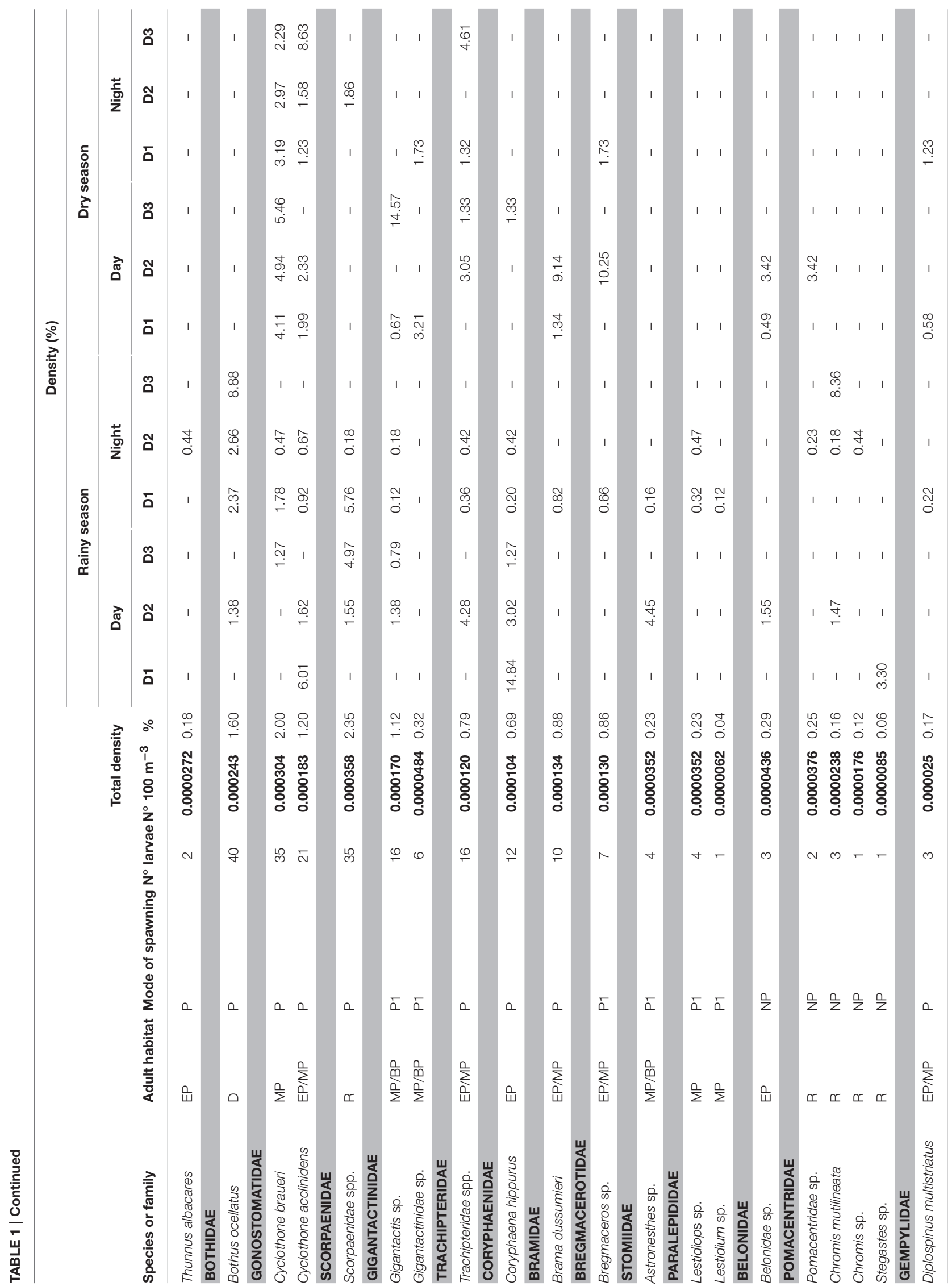




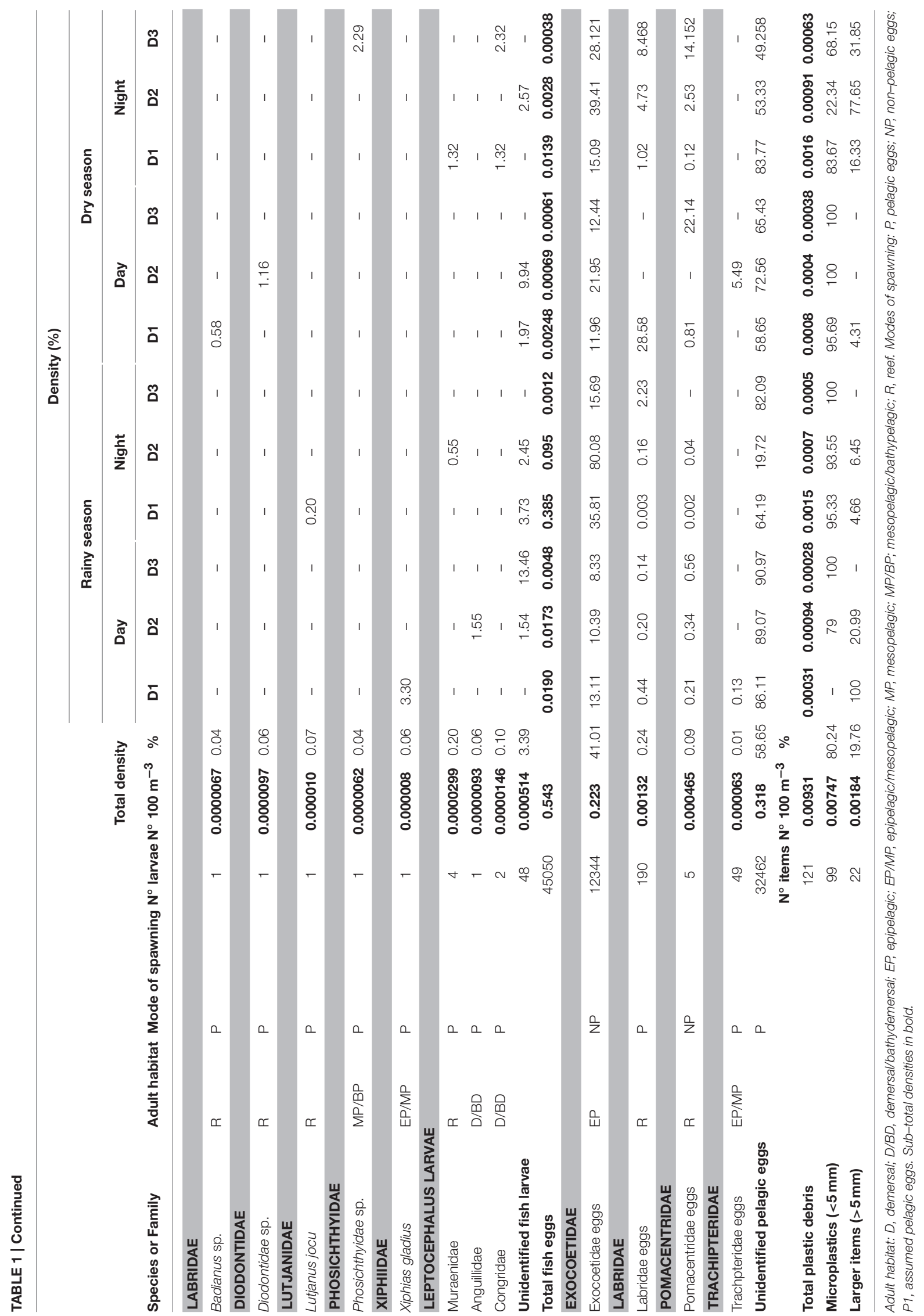


warmingii was second in rank at 0.0018 ind. $100 \mathrm{~m}^{-3}(12.16 \%)$ followed by the reef blenny Entomacrodus vomerianus $(0.0015$ ind. $\left.100 \mathrm{~m}^{-3}-10.44 \%\right)$. The family Myctophidae had the highest species richness (15), followed by Exocoetidae (6), Pomacentridae (4), Blennidae (3) and Scombridae (3) (Table 1). Unidentified pelagic eggs represented the majority of the eggs captured $(32,462$ eggs-58.65\%). From the remaining eggs, four families were identified: Exocoetidae (41.01\%), Labridae (0.24\%), Pomacentridae (0.09\%), and Trachpteridae (0.01\%) (Table 1).

Eleven species were exclusive to D1 (e.g., Hirundichthys sp. and Lampanyctus alatus), 7 to D2 (e.g., Nannobrachium lineatum and Thunnus albacares) and 3 to D3 (e.g., Myctophum asperum and Lepidophanes guentheri) (Table 1). Seventeen taxa were common to the three distances: O. micropterus, Exocoetidae sp., C. warmingii, C. maderensis, Dyaphus sp., Myctophidae spp., Electrona risso, Ophioblennius macclurei, Serranidae sp., Thunnus obesus, Bothus ocellatus, Cyclothone braueri, C. acclinidens, Scorpaenidae spp., Gigantactis sp., Trachpteridae spp., and Coryphaena hippurus (Table 1). Eighteen species were exclusive to the night period (e.g., E. vomerianus and Lestidiops sp.), while only 8 was exclusively captured during the day (e.g., L. guentheri and Hirundichthys sp.). Species richness was observed to decrease with sampling distances from the Archipelago. Nearshore catches had the highest species richness (44), followed by intermediate nearshore (38) and offshore (26).

In total, 99 individual items of microplastic and 22 of larger items were collected. SPSPA was contaminated with $47.2 \%$ ( $n=$ 34) of all samples containing plastic debris (Table 1). The most common fragment was hard plastic $(n=46)$, followed by threads $(n=26)$, paint chips $(n=25)$, rubber crumbs $(n=19)$ and soft plastic $(n=5)$. The most common color was blue ( $n=40)$, followed by black $(n=27)$ and white $(n=23)$. Hard plastic represented $44.4 \%$ of the total microplastic and threads represented $77.3 \%$ of the total larger items. All items together accounted to a total density of 0.0093 items $100 \mathrm{~m}^{-3}$, which is $\sim 1.63$ times less abundant than the total fish larvae density (Figure 3). However, analysing by individual taxa, plastic density was $\sim 2.12$ times more abundant than the most abundant fish larvae (O. micropterus). Plastics were common to all three distances during the day and at night, in rainy and dry periods (Figure 4 and Table 1).

\section{Distribution Patterns of Ichthyoplankton and Plastic Debris}

The three-way ANOVA results showed that fish larvae and plastics did not differ among season, distances and day/night periods (Figure 4 and Table 2). Fish eggs differed among the three factors $(p<0.05)$ (Figure 4 and Table 2). The interactions season vs. distance vs. period were also significant for these variables $(p<0.05)$ (Figure 4 and Table 2). Such interactions suggest that seasonality and the period of the day are influencing the distribution of ichthyoplankton and plastics around the Saint Peter and Saint Paul Archipelago.

At distances D1 and D2, fish larvae and fish eggs had higher densities in the rainy season during the night (Figure 4). During the dry period, fish larvae had higher densities during the day, while fish eggs in the night. At distance D3, fish larvae and eggs had higher densities by day during both seasonal periods (Figure 4). The highest average densities of fish eggs and larvae occurred during the rainy season by night at D1 and D2, respectively ( $p<0.05$ ) (Figure 4 and Table 2 ). On the other hand, plastics had higher densities during the night at the three distances, independent of season, except during the rainy period at D2, when they had similar densities for both periods (Figure 4). Interactions showed that the highest average density of plastics occurred during the dry season by night at D1 $(p<$ 0.05) (Figure 4 and Table 2).

\section{Distribution Patterns of Main Ichthyoplankton}

The ANOVA showed that the mean density of the 7 most frequent taxa differed either among season, distance and/or period (Figure 5 and Table 2). Larval O. micropterus had higher densities in the rainy season during the night at D1 and D2 (Figure 5). This species was absent by night at D3, being represented only during the day in both season. The highest average density of $O$. micropterus occurred during the rainy season by night at D2 $(p<0.05)$ (Figure 5 and Table 2). Larval C. warmingii and C. maderensis presented higher densities in the rainy season during the night and in the dry season during the day at the three distances (Figure 5). However, during the rainy season by day at D1 and D3, C. maderensis and C. warmingii were absent, respectively. In addition, larval C. maderensis were not captured in the rainy season at D3. Interactions showed that the highest average densities of larval C. maderensis were observed during the dry season by day at D1 $(p<0.05)$. Larval E. vomerianus was absent at D3 (Figure 5). It had higher densities during the night at D1 and D2 in both seasons, with highest average density at D1 during the rainy season $(p<0.01)$ (Figure 5 and Table 2). Larval O. macclurei and Serranidae spp. were absent during the dry season at D1 and D3, and during the rainy season during the night at D3 (Figure 5). This species had higher densities during the rainy period by night at D1 and D2, with highest average densities at D1 $(p<0.01)$ (Figure 5 and Table 2). Larval T. obesus was absent during the dry season, and during the rainy season by night at D2 and D3 (Figure 5). Their absence was also observed during the dry season by night at D1. Their highest average density occurred during the rainy season by day at D3 $(p<0.01)$.

\section{Distribution of Fish Larvae According to Their Habitat}

The ANOVA showed that the distribution of fish larvae according to their 7 adult habitats differed either among season, distance and/or period (Figure 6 and Table 2). Larval demersal species were absent in the dry season in the three distances and in the rainy season during the day at D1 and D3. The highest densities were observed during the rainy season by night at the three distances $(p<0.01)$ (Figure 6). Larval demersal/bathydemersal species were absent during the rainy season, and dry season during the day at D1 and D3. They were also absent in the dry season, and rainy season by night at D2 (Figure 6). Although 


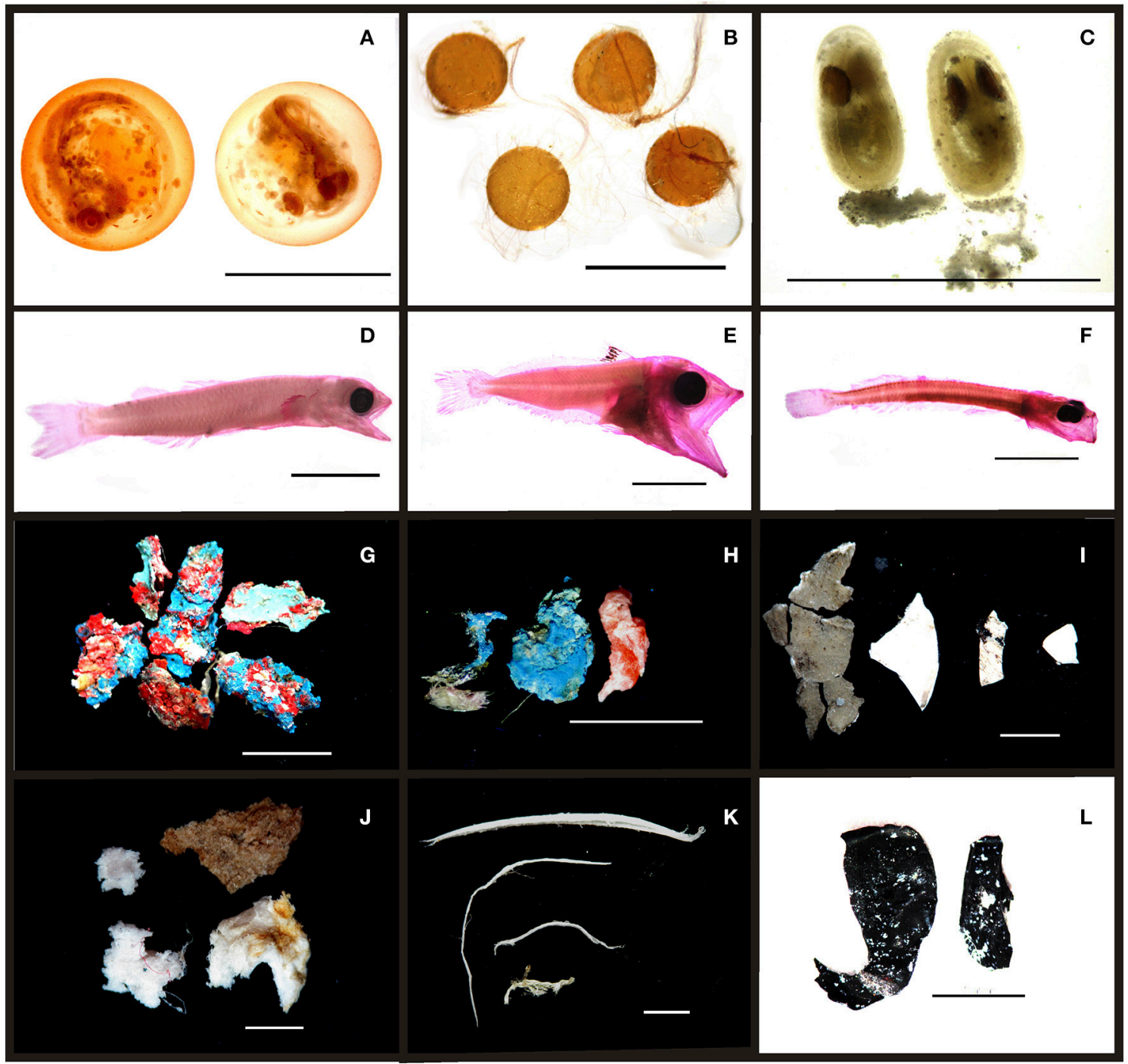

FIGURE 3 | Examples of ichthyoplankton and plastic debris in Saint Peter and Saint Paul Archipelago. (A) Trachpteridae eggs; (B) Exocoetidae eggs; (C) Pomacentridae eggs; (D) Ceratoscopelus warmingii; (E) Thunnus obesus; (F) Oxyporhamphus micropterus; (G) paint chips; (H) hard plastics; (I) soft plastics; (J) rubber cumber; (K) threads; (L) soft plastics.

significant differences have been not detected, their densities were high by night at D1 and D3 and by day at D2. Larval epipelagic and epipelagic/mesopelagic species were absent only in rainy season during the night at D3, with highest average densities during the rainy season by night and dry season by day at D2, respectively ( $p<0.05$ ) (Figure 6 and Table 2). Interactions suggest that larval mesopelagic species presented highest densities in the rainy season during the night and in the dry season during the day at the three distances $(p<$ 0.01) (Figure 6 and Table 2). Larval mesopelagic/bathypelagic species were absent during the dry season at D2 and during the rainy season by day at D1 and by night at D3, with highest average density in the dry season during the day at D3 $(p<0.05)$ (Figure 6 and Table 2). Larval reef species were absent during the dry season at D1 and D3, with highest average density in the rainy season during the night at D1 $(p<0.05)$

\section{Influence of the Environmental Variables in Ichthyoplankton and Plastic Distributions}

The CCA showed that the first axis of the correlations between species and habitat with oceanographic variables explained 61.1 and $49.1 \%$, respectively, of the variance of the species/habitat/microplastic-environment relation, and represented seasonality (dry and rainy) (Figures 7A,B). The first axes showed negative correlation with rainfall for species relations $(p<0.01)$ and negative correlation with wind velocity for habitat relations ( $p<0.01$ ) (Figures 7A,B and Table 3). The second axes explained $19 \%$ and $24.6 \%$ for species and habitat relations, respectively, and represented the period of the day (day 
D1
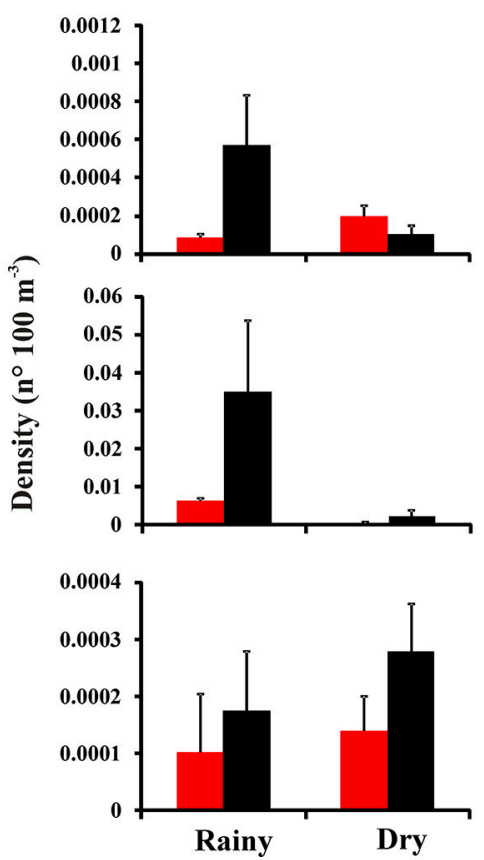

$\mathbf{D 2}$
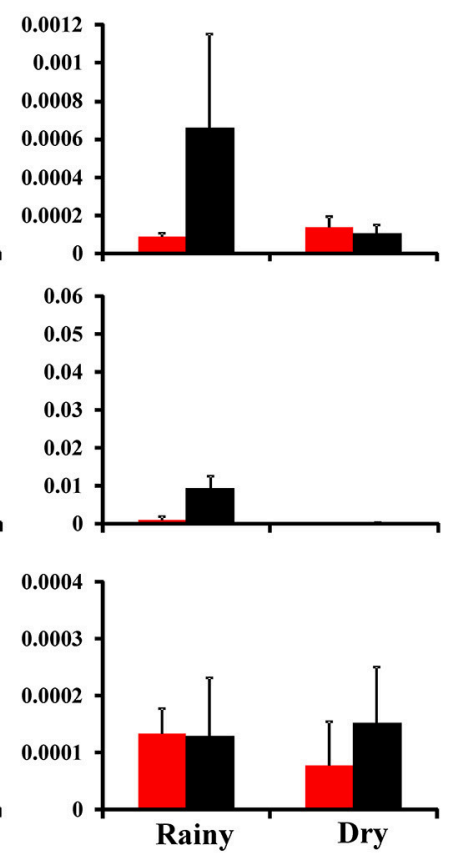

D3
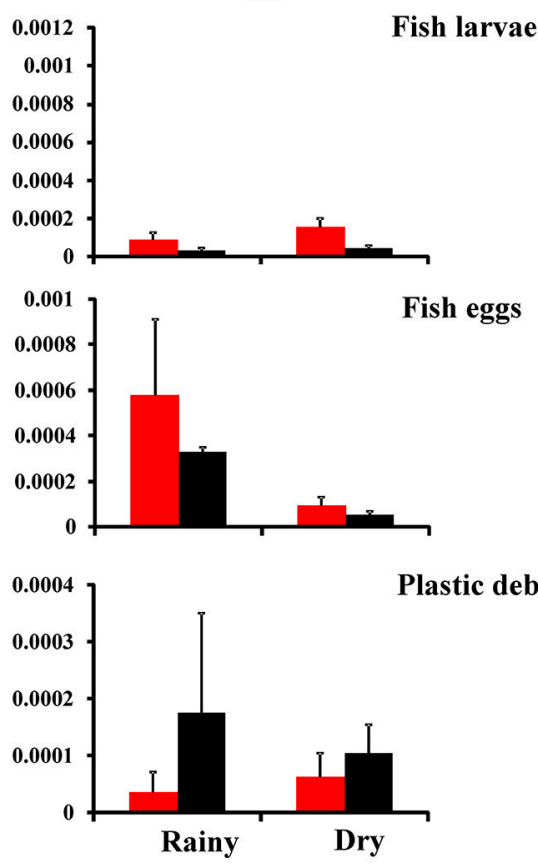

FIGURE 4 | Total mean (+S.E.) density of ichthyoplankton (fish larvae and fish eggs) and plastics in different periods [( $\square$ ) day and ( $\square$ ) night] at D1 $(<100 \mathrm{~m})$, D2 (>100-500 m), and D3 (>500-1500 m) for each season (rainy and dry).

and night) (Figures 7A,B). Higher temperatures, lower wind velocity and lower Chlorophyll $a$ characterized the rainy season. Northwest winds were prevalent during the rainy season and southwest winds during the dry season (Figures 7A,B).

During the rainy season, Serranidae spp., O. micropterus, fish eggs, and O. macclurei showed positive correlation with higher rainfall and higher temperatures. The first two taxa were abundant especially at D1 and D2 during the day and the other two at D1 and D3 during the night (Figure 7A). Thunnus obesus and E. vomerianus were positively correlated with day and night, respectively, especially during the rainy season. Larval epipelagic, reef, and demersal species were also positively correlated with higher rainfall and higher temperatures (Figure 7B). Larval epipelagic and reef species were correlated with the three distances. The former were abundant especially by day, whereas larval reef species were by night. Larval demersal species were present only during the rainy season, independent of the distance from the archipelago (Figure 7B).

During the dry season, C. maderensis, C. warmingii and plastics showed positive correlation with higher wind velocity, higher Chlorophyll $a$ and southwest winds, especially at D1 and D3 (Figure 7A). The two taxa were more abundant by day, whereas plastics showed ubiquity trends with positive correlation with night periods (Figure 7A). Larval mesopelagic and epipelagic/mesopelagic species and plastics also showed positive correlation with higher wind velocity, higher Chlorophyll $a$ and southwest winds. These species were abundant during the day especially at D1 and D2. Plastics were abundant by night, but ubiquitous (Figure 7B). Larval demersal/bathydemersal species showed strong positive correlations with the day period, and larval mesopelagic/bathypelagic species with the night period, both during the dry season (Figure 7B).

\section{DISCUSSION}

\section{Seasonal Influence of Oceanographic Variables on the Distribution of Ichthyoplankton Assemblages}

This study revealed that SPSPA is surrounded by 4 main larval fish assemblages. Leptocephalus larvae (Anguillidae and Congridae) and the lowest species richness characterized the first assemblage, which comprised larvae of demersal/bathydemersal spawners, common at night. The second assemblage had the highest species richness because it comprised most larvae of the family Myctophidae, as well as most larvae of less abundant pelagic spawners such as $T$. obesus, Cyclothone acclinidens, and Brama dussumieri. This assemblage included larvae of mesopelagic, mesopelagic/bathypelagic and epipelagic/mesopelagic spawners common during the day. The lower temperature, higher Chlorophyll $a$, higher wind velocity and the southwest winds of the dry season influenced both these assemblages. The third assemblage included larvae of epipelagic spawners common during the day, such as Exocoetidae larvae, Coryphaena hippurus, Belonidae sp. and two Scombridae species (Katssuwonus pelamis and T. albacares). The fourth assemblage comprised larvae of reef and demersal spawners common at night, and characterized by larvae of the families 
TABLE 2 | Summary of the ANOVA results for the mean density of fish larvae, fish eggs, and plastic debris.

\begin{tabular}{|c|c|c|c|c|c|c|c|}
\hline \multirow[b]{2}{*}{ Variables } & \multicolumn{3}{|c|}{ Source of variance } & \multicolumn{4}{|c|}{ Interactions } \\
\hline & Season (1) & Distance (2) & Period (3) & $1 \times 2$ & $1 \times 3$ & $2 \times 3$ & $1 \times 2 \times 3$ \\
\hline Fish larvae & ns & ns & ns & ns & * & ns & * \\
\hline Oxypohamphus micropterus & ns & ns & ns & ns & ns & ns & * \\
\hline Ceratoscopelus warmingii & Dry rainy ${ }^{\star}$ & ns & ns & * & * & * & * \\
\hline Entomacrodus vomerianus & ns & ns & Day night* & * & * & * & ** \\
\hline Ceratoscopelus maderensis & Dry rainy* & ns & ns & * & * & ns & * \\
\hline Serranidae spp. & Dry rainy* & ns & ns & 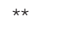 & * & * & ** \\
\hline Ophioblennius macclurei & ns & ns & Day night* & * & ** & ns & * \\
\hline Thunnus obesus & Dry rainy ${ }^{\star \star}$ & D2 D1 D3* & Day night** & ** & ** & * & * \\
\hline \multicolumn{8}{|l|}{ LARVAL SPECIES HABITAT } \\
\hline Demersal & Dry rainy ${ }^{\star *}$ & ns & Day night** & * & ** & ** & ** \\
\hline Demersal/Bathydemersal & ns & ns & ns & ns & ns & ns & ns \\
\hline Epipelagic & ns & ns & Ns & ns & * & $\mathrm{ns}$ & ** \\
\hline Epipelagic/Mesopelagic & ns & ns & Day night* & ns & * & ns & * \\
\hline Mesopelagic & ns & ns & Ns & * & ** & ns & * \\
\hline Mesopelagic/Bathypelagic & ns & ns & ns & * & * & * & * \\
\hline Reef & ns & ns & Day night* & $\star *$ & ** & * & * \\
\hline Fish eggs & Dry rainy* & D3 D2 D1* & Day night* & * & * & * & * \\
\hline Plastic debris & ns & ns & ns & ns & ns & * & * \\
\hline
\end{tabular}

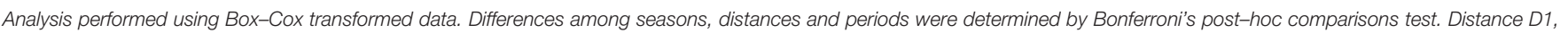
$<100 \mathrm{~m} ; \mathrm{D} 2,>100-500 \mathrm{~m} ; \mathrm{D} 3,>500-1500 \mathrm{~m}$. ns, not significant; ${ }^{* *} \mathrm{p}<0.01 ;{ }^{*} p<0.05$.

Blennidae, Serranidae, Pomacentridae, Scorpaenidae, Labridae, Diodontidae, Lutjanidae, Muraenidae, and Bothidae. Higher temperatures and the northwest winds of the rainy season influenced these two last assemblages.

Despite the fact that species richness decreased from nearshore (D1) to offshore (D3) samples, spatial influences were not as pronounced as observed in other studies of oceanic islands. These studies show that each distance has distinct or transitional oceanographic characteristics that influence the composition of larval fish assemblages. Nearshore assemblages are those most represented by island/reef taxa (e.g., Serranidae, Blennidae), transitional oceanic assemblages by mesopelagic fish larvae (e.g., Myctophidae) and offshore assemblages by oceanic taxa (e.g., Gonostomatidae, Exocoetidae) (Boehlert et al., 1992; Nonaka et al., 2000; Macedo-Soares et al., 2012). In our study, larval species exclusive of a single distance from the archipelago were rare during specific seasons or day/night periods, what is not enough to characterize an assemblage. In a previous interannual study at SPSPA, larval fish assemblages were highly driven by spatial and day/night influences (Macedo-Soares et al., 2012). Variations in assemblages structure in the same study area might be driven by differences in the composition and abundance of fish larvae when more than 1 year is considered, whereas their densities per years are coupled and include peaks, when compared with a seasonal study.

Although offshore samples were dominated by few larval species $(\sim 5)$ of epipelagic and mesopelagic spawners, larvae of some reef spawners were also captured offshore. Also, larvae of epipelagic and mesopelagic species were found nearshore. This composition is more similar to a transitional assemblage, such as described for the Abrolhos Bank (Eastern Brail) (Nonaka et al., 2000). In addition, the abrupt topography of SPSPA shortens the distances between reef, neritic and oceanic environments favoring the mix of species of different ecological guilds in the same assemblage (Boehlert and Mundy, 1993; Macedo-Soares et al., 2012). In the Medes Islands (Northwest Mediterranean) larvae of some shorefish species disperse toward the open ocean, while other species remains in the vicinity of the adults, suggesting that pelagic larvae are not dependent on passive dispersal (Sabatés et al., 2003). This emphasizes the fact that the horizontal annual distribution of the ichthyoplankton at SPSPA suggest a dependence on the physical conditions of the environment, independent of the distances from the archipelago.

A clear pattern in the present study is related to a fish egg pulse in the rainy season at nearshore distances, which also coincided with the pulse of fish larvae. The high abundance of eggs and larvae of $O$. micropterus strongly influenced these two pulses. The rainy season was important for the earlier phases of O. micropterus and probable spawning season of Exocoetidae species. In contrast, the dry period was very important for larval Myctophidae C. warmingii and C. maderensis, although pulses were not observed. In the Gran Canaria Island (Northeast Atlantic), seasonality also showed a strong influence on the annual larval assemblages than sampling site, resulting in two seasonal larval assemblages: a mixed and a stratified assemblage (Moyano et al., 2014). At Rottnest Island (Western Australia), recruitment pulses of fish larvae were recorded in La Nina and El Nino years related with stronger and weaker Leeuwin Current, respectively (Pearce and Hutchins, 2009). These results show that in some areas, seasonal oceanic processes or even small-scale 


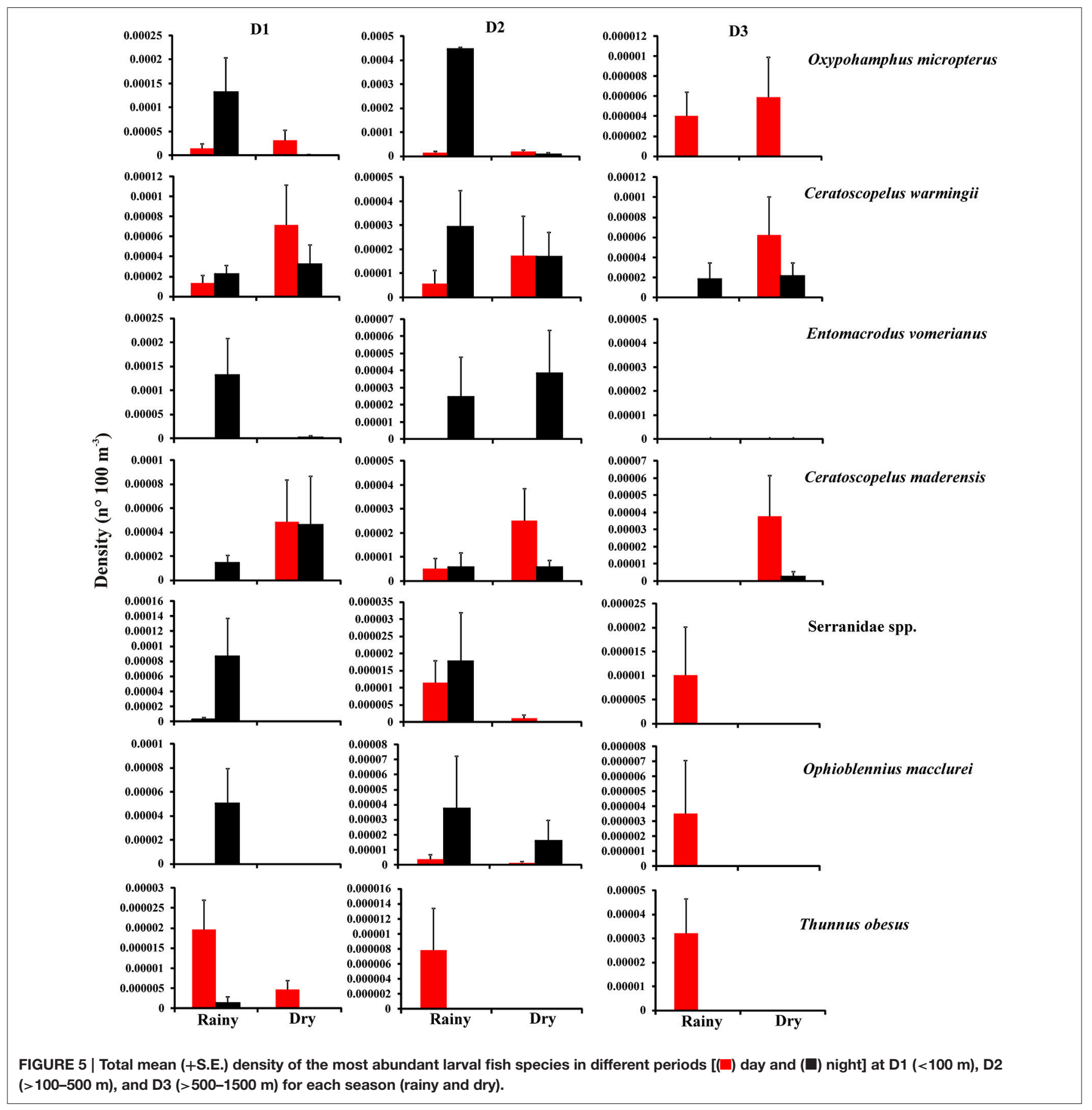

temporal events can be stronger factors driving the formation of larval fish assemblages than do spatial distribution of habitats around the oceanic islands (Pearce and Hutchins, 2009; Moyano et al., 2014).

The interaction between the topography and the system of currents (SEC and EUC) near SPSPA produces vortices, disturbances of the thermohaline structure and possible mechanisms of local upwelling (Melo et al., 2012). In the present study, the northwest and southwest winds reaching the west side of the islands and the South Equatorial Current flowing eastward seems to be responsible for the nearshore retention of fish larvae due to the creation of surface eddies around the archipelago. Although upwelling is likely to be responsible by the dispersion of larvae toward the open ocean, at SPSPA these events seem to have a combined effect with eddies for the retention of fish larvae near the archipelago, such as observed in the Canary Current System during a weak upwelling season (Moyano et al., 2014). Areas of retention of pelagic larvae of island related taxa maybe due to the combination of current flow, topography and formation of eddies and upwelling, as reported at Johnston Atoll 


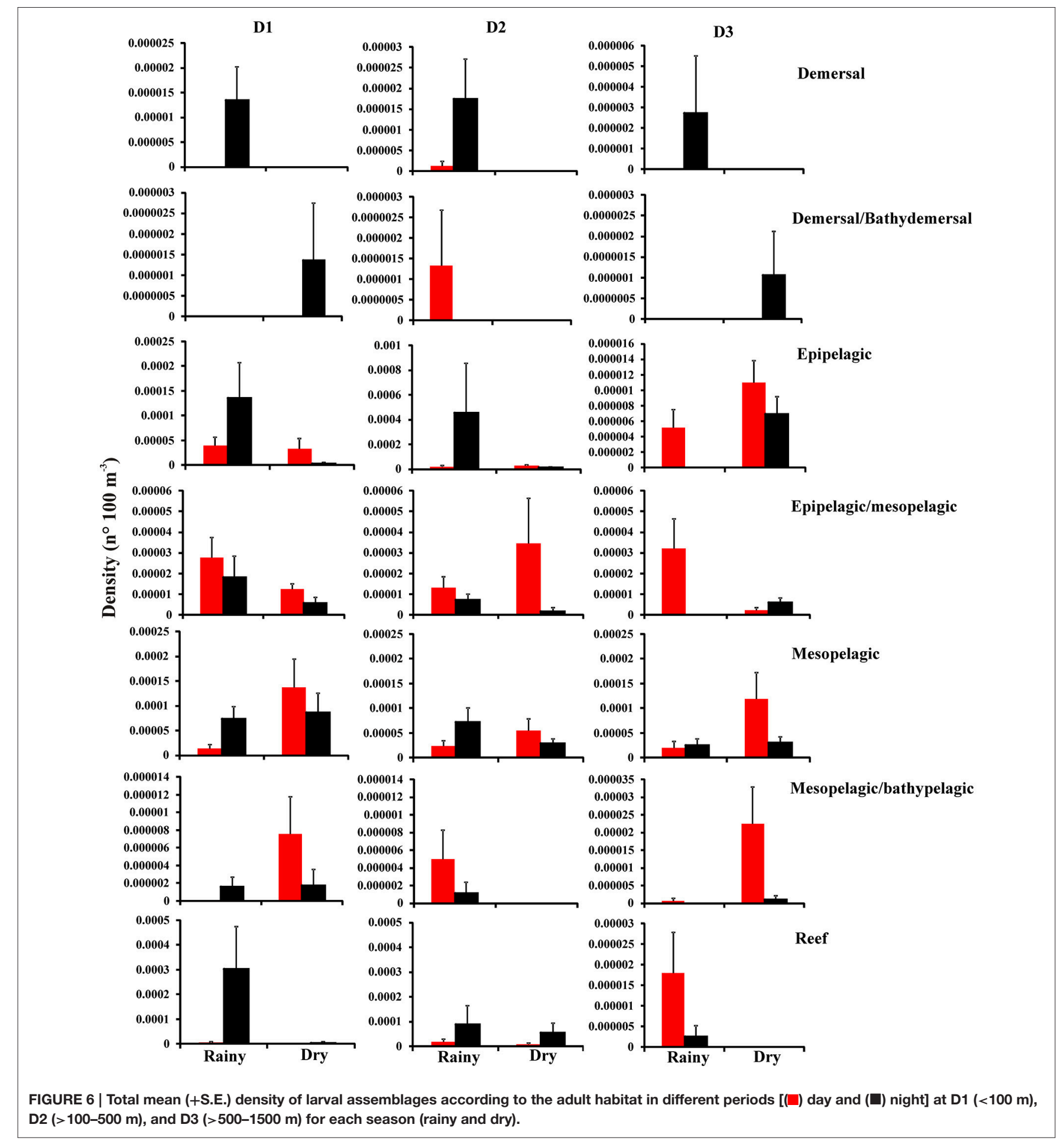

(Central Pacific Ocean) (Boehlert et al., 1992), Great Meteor Seamount (Diekmann et al., 2006), and near the Canary Islands (Moyano et al., 2014). In addition, a clear windward-leeward distribution pattern was also observed for neritic larvae during the late winter bloom off Gran Canaria Island (Moyano et al., 2014).

During the rainy season at nearshore distances (D1 and D2), dominant species were highly abundant during the night, suggesting a diel vertical migration. The highest oceanic productivity in midlatitude occur between March and April, when temperatures and precipitation are higher, favoring the appearance of fish larvae predators due to increased food availability (Joo et al., 2016). These months coincide with the rainy season at SPSPA. The distribution patterns observed for the dominant species seem to be associated with specific behavior of predator avoidance. During the dry season and at offshore 

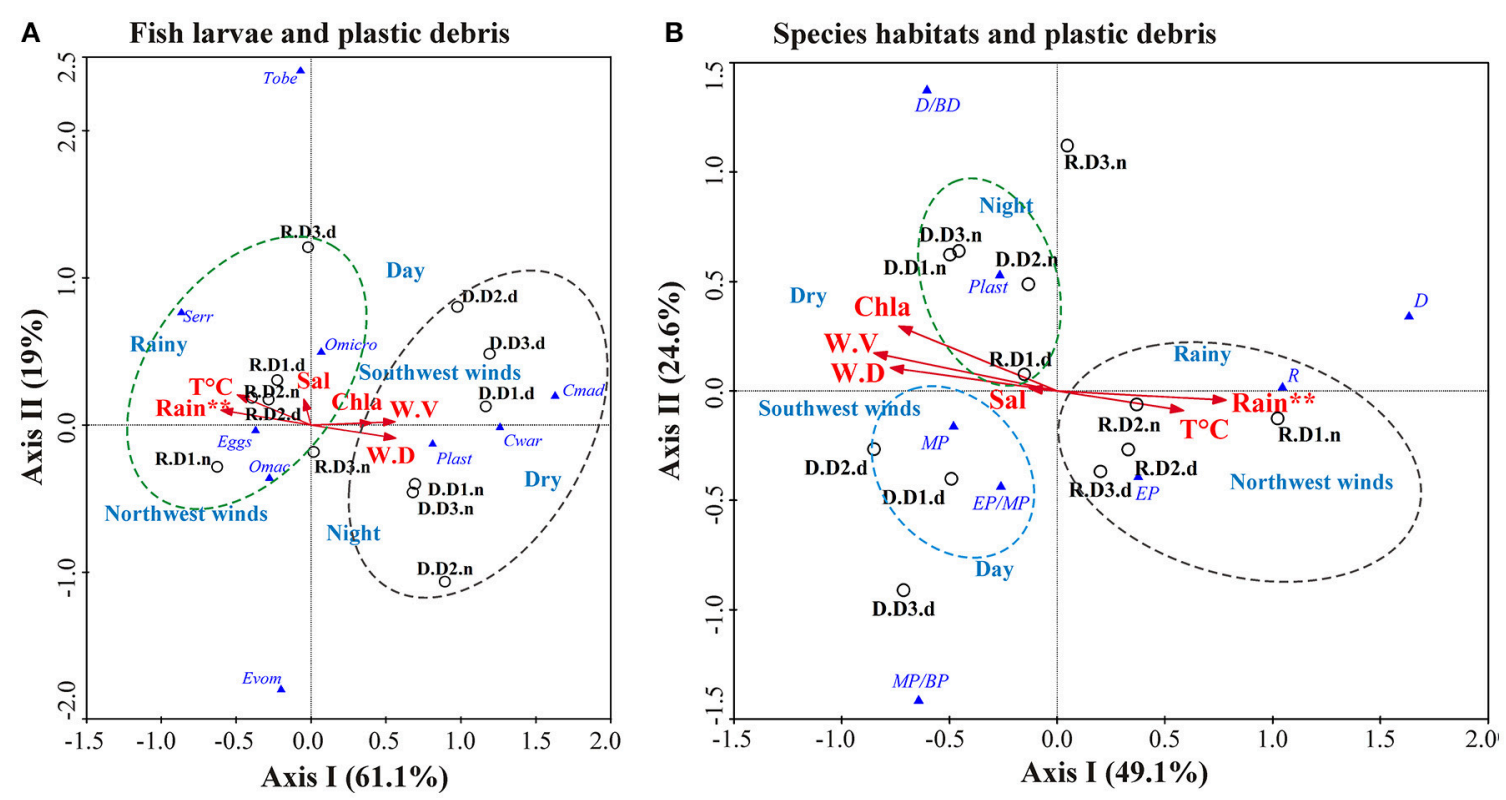

FIGURE 7 | Canonical correspondence analysis (CCA) triplot for the ecological correlations between the (A) ichthyoplankton/plastics and (B) larval assemblages/plastics and the oceanographic variables. Circles (o) represent the three distances from the Archipelago [D1 (<100 m), D2 (>100-500 m) and D3 (>500-1500 m)] during each season [R (Rainy season) and D (Dry season)] and period (d, day; $n$, night). Triangles ( $\mathbf{\Delta}$ ) represent the plankton [ichthyoplankton (Cmad,Ceratoscopelus maderensis; Cwar, Ceratoscopelus warmingii; Eggs, fish eggs; Evom, Entomacrodus vomerianus; Omac, Ophioblennius macclurei; Omicro, Oxyporhamphus micropterus; Serr, Serranidae spp.; Tobe, Thunnus obesus), larval species habitats ( $D$, demersal; $D / B D$, demersal/bathydemersal; $E P$, epipelagic; $E P / M P$, epipelagic/mesopelagic; $M P$, mesopelagic; $M P / B P$, mesopelagic/bathypelagic; $R$, reef), and plastic debris (Plast)]. The environmental variables [rainfall, chlorophyll $a$, salinity, temperature, wind direction (W.D.) and wind velocity (W.V.)] were represented by arrows. ${ }^{\star \star} p<0.01$.

distances (D3) they were abundant during the day, possibly because productivity decreased, and thus predator avoidance, were a secondary problem for their survival. The influence of day and night periods on larval fish assemblages was also observed in Cobb Seamount (Northeast Pacific) and Great Meteor Seamount (Northeastern Atlantic), being an indicative of changes in the vertical distribution of fish larvae (Dower and Perry, 2001; Diekmann et al., 2006).

At SPSPA the specie richness of reef fishes is relatively high, accounting for 52 species form a checklist of 116 taxa (Vaske et al., 2005). From these, 13 taxa were recorded as reef larvae in the present study, with E. vomerianus and Serranidae spp. dominating the larval community. The low abundance, or total absence, of some reef taxa might be caused by differences in the distances sampled, which contributes to differences in larval assemblage composition. In some studies, oceanic assemblages were identified in samples collected $3 \mathrm{~km}$ away from the island (Leis and Miller, 1976; Macedo-Soares et al., 2012); as well reef fish larvae have been collected hundreds of kilometers far from nearshore (Victor, 1987). An interannual study at ASPSP showed that the most abundant larval reef taxa were the endemic Stegastes sanctipauli (Pomacentridae) and E. vomerianus, predominantly found inside the cove and in tidal pools, respectively (MacedoSoares et al., 2012). This was probably related to self-recruitment strategies, since these species release non-pelagic eggs, which helps to keep larvae near their adult habitat (Macedo-Soares et al., 2012). In the present study, cove samplings were not conducted, however, the genus Stegastes was recorded at D1 and E. vomerianus was the third most abundant taxa.

Distribution of tuna larvae (Scombridae), particularly of the commercially important genera Thunnus, have been extensively investigated to identify spawning locations (Leis et al., 1991; Boehlert and Mundy, 1994; Fowler et al., 2008). Although not highly abundant, Thunnus obesus was well represented during the rainy season (day period), especially at distances $>500 \mathrm{~m}$ up to $1.5 \mathrm{~km}$ from SPSPA. Low mean concentration of tuna larvae have been recorded in many oceanic studies, due to their broad geographical range and spawning patterns (Leis et al., 1991). However, higher concentrations of tuna larvae were found in studies of tropical near-reef locations, such as in nearreef waters of the Coral Sea, Lizard Island-Australia (Fowler et al., 2008) and Oahu Island, Hawaii (Miller, 1979). These results emphasize the importance of remote oceanic islands and seamounts as hotspots of fish biodiversity, which include ecological and commercial important taxa, reinforcing the need of management for the conservation of these ecosystems.

\section{Distribution of Plastics and the Effects of Their Occurrence Together with Fish Larvae}

More than $119,000 \mathrm{~m}^{3}$ of seawater were filtered during the samplings. This resulted in a total density of plastic debris $(>0.15-23.46 \mathrm{~mm})$ of $\sim 0.01$ items per $100 \mathrm{~m}^{3}$. The average number of plastic debris was $1.7 \pm 2.56$ items per sample. 
TABLE 3 | Summary of canonical correspondence analysis (CCA) using six environmental variables (water temperature, salinity, rainfall, chlorophyll a, wind velocity and wind direction) and density of fish larvae species, fish eggs, larval species habitats and plastic debris in the Saint Peter and Saint Paul Archipelago.

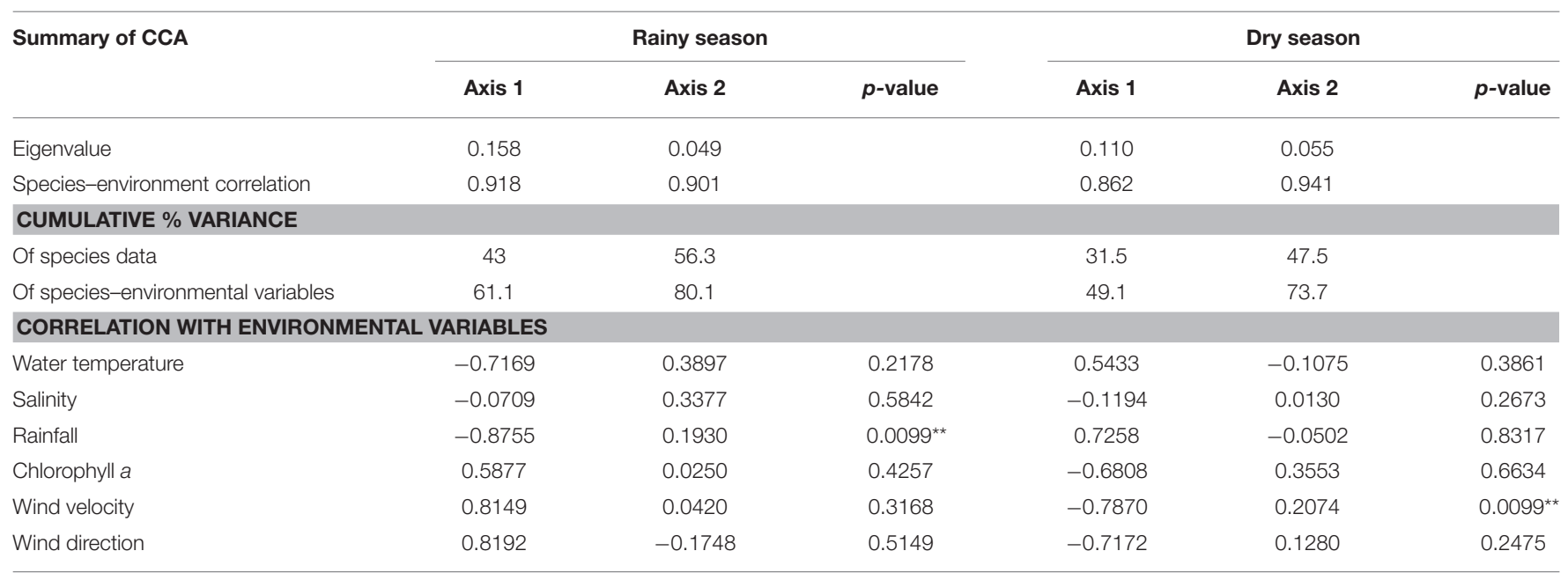

${ }^{\star \star} p<0.01$

Although $47.2 \%$ ( $n=34$ ) of samples were contaminated, plastic debris were found at least in one replica of each treatment (i.e., distance, daily periods and season) per month. Thus, the results of our study confirmed that plastics are present in every distances around the SPSPA (Ivar do Sul et al., 2013), independent of seasons or periods, being considered ubiquitous with positive correlation with night periods and sharing the same habitats of larval fish community.

The sources of microplastic pollution to coastal environments are likely river basins, mangrove forests and adjacent beaches due to domestic, recreational and artisanal/commercial fishery activities (Guebert-Bartholo et al., 2011; Possatto et al., 2011; Ramos et al., 2012). In the ocean, the accumulation of buoyant plastics in the center of subtropical gyres are due to surface currents and winds (Moore, 2008; Maximenko et al., 2012). However, in remote oceanic islands as SPSPA, mechanisms that facilitate the presence and distribution patterns of microplastics are not fully known. Phenomena as particle aggregation, animal activities and currents may bring plastics. However, another probable source of plastic debris for SPSPA is the small and constant fishing fleet (Ivar do Sul et al., 2013), which have been responsible for a shark population extinction in the archipelago (Luiz and Edwards, 2011; Ivar do Sul et al., 2013). The presence of plastic threads $(22 \%$ of the total debris and $77.3 \%$ of the total larger items) is likely related to these fishing activities around the area, suggesting that at least a part of these fragments ere locally sourced (Guebert-Bartholo et al., 2011; Ivar do Sul et al., 2013; Chen, 2015; Costa and Barletta, 2015). Small-scale oceanic mechanisms that retain fish larvae close to the archipelago are likely also promoting the trapping of microplastics.

Due to variations in sampling methods and effort, as well as differences in oceanographic variables of the regions, care is needed to compare oceanic ecosystems regarding the density of plastic debris. The mean density of plastic debris (micro and larger items) found at SPSPA waters was 0.00013 items per 100 $\mathrm{m}^{3}$ in both rainy and dry periods. These values are much lower than those found in the Northeast Pacific ocean (Southeast Bering Sea), where mean density varied from 0.4 to 19 items $100 \mathrm{~m}^{-3}$ (Doyle et al., 2011). In Northeast Atlantic Ocean and Artic Polar waters, mean density reached 246 items $100 \mathrm{~m}^{-3}$ (Lusher et al., 2014) and 34 items $100 \mathrm{~m}^{-3}$ (Lusher et al., 2015), respectively. The total density of plastics around SPSPA was $\sim 0.01$ items 100 $\mathrm{m}^{-3}$ and varied from 0.0049 items $100 \mathrm{~m}^{-3}$ in the dry season to 0.0044 items $100 \mathrm{~m}^{-3}$ in the rainy season. When compared to other studies, the total density of plastics in SPSPA are low. For example, in the coastal ocean near Long Beach (California), plastic densities varied from 1000 items $100 \mathrm{~m}^{-3}$ during the dry season to 6000 items $100 \mathrm{~m}^{-3}$ after a storm event (Moore et al., 2002). SPSPA still presents a much smaller density when compared with a study conducted from the European Coast to the North Atlantic Subtropical Gyre, where plastic densities varied from 1300 to 50,100 items $100 \mathrm{~m}^{-3}$ (Enders et al., 2015). However, when compared with studies in pelagic waters around three oceanic islands of the Western Atlantic ( $n=243$ particles), the density of plastics at SPSPA ( $n=121$ particles) were on the same order of magnitude as that around Abrolhos Archipelago (0.04 items $100 \mathrm{~m}^{-3}$ ), Fernando de Noronha Archipelago (0.015 items $\left.100 \mathrm{~m}^{-3}\right)$ and Trindade Island (0.025 items $100 \mathrm{~m}^{-3}$ ) (Ivar do Sul et al., 2014).

Studies on the relationships between the abundance of planktonic organisms and plastic debris in the water column suggest that comparable amounts increase their chances of interactions (Collignon et al., 2014; Long et al., 2015; Panti et al., 2015; Lima et al., 2015, 2016). The density of plastic at SPSPA ( 0.0093 items $100 \mathrm{~m}^{-3}$ ) were on the same order of magnitude of the most abundant larval species O. micropterus $(0.0044$ larvae $100 \mathrm{~m}^{-3}$ ). In addition, during specific times, plastics surpassed the total ichthyoplankton density at specific distances. Interactions of these fragments with planktonic organisms and 
their predators have also been reported (Lima et al., 2015, 2016; Long et al., 2015; Panti et al., 2015; Cole et al., 2016). These organisms are prone to feed on available microplastics and promote the transfer of particles and sorbed pollutants throughout the trophic web (Dantas et al., 2012; Lusher et al., 2013; Rochman et al., 2013; Tanaka et al., 2013; Besseling et al., 2014; Sá et al., 2015; Ferreira et al., 2016; Lönnstedt and Eklöv, 2016; Wardrop et al., 2016).

Microplastics have been reported to widely pollute all marine environments including subtropical gyres, estuaries and remote oceanic islands (Ivar do Sul et al., 2013; Lima et al., 2014; Costa and Barletta, 2015; Lusher, 2015). Whereas plastic debris are mixed with larval assemblages around SPSPA, the main concern of this study is the reduction of the nursery function and of the feeding area of this archipelago if fish larvae are ingesting plastic fragments. Predators can feed on plastic debris of the same order and shape as major zooplankton taxa in the area. For example, flexion and post-flexion fish larvae $(>7 \mathrm{~mm})$ can prey on microplastic, especially those smaller than $1 \mathrm{~mm}$ (47.9\% of the total number) and then be consumed by top predators (Barnes et al., 2009; Boerger et al., 2010; Cole et al., 2011; Wright et al., 2013; Ferreira et al., 2016). This disturbance of the trophic web is also possible at ASPSP. The marine food web has been demonstrated to conduct the transfer of microplastic from one place to another, especially when they are preyed by migratory taxa such as marine birds and tuna (Vaske et al., 2005; Farrell and Nelson, 2013). Although new effects of microplastics pollution in the marine environment are constantly revealed, effects caused by ingestion of microplastics include contamination by persistent organic pollutants, biocides and trace metal, gut blockage and starvation (Turner, 2010; Cole et al., 2011; Costa and Barletta, 2015). High quality information are necessary to understand possible pathways and sources

\section{REFERENCES}

Amaral, F. M. D., Rocha, C. M. C., Farrapeira, C. M. R., and Alves, M. S. (2009). "Distribuição espacial de invertebrados bentônicos infralitorais," in $O$ Arquipélago de São Pedro e São Paulo: 10 anos de Estação Coentífica, ed F. H. V Hazin (Brasília: SECIRM), 148-156.

Barnes, D. K. A., Galgani, F., Thompson, R. C., and Barlaz, M. (2009). Accumulation and fragmentation of plastic debris in global environments. Philos. Trans. R. Soc. B Biol. Sci. 364, 1985-1998. doi: 10.1098/rstb.200 8.0205

Bernardi, G. (2013). Speciation in fishes. Mol. Ecol. 22, 5487-5502. doi: $10.1111 / \mathrm{mec} .12494$

Besseling, E., Wang, B., Lürling, M., and Koelmans, A. A. (2014). Nanoplastic affects groeth of $S$. obliquus and reproduction of D. magna. Environ. Sci. Technol. 48, 12336-12343. doi: 10.1021/es503001d

Boden, B. P., and Kampa, E. M. (1953). Winter cascading from an oceanic island and its biological implication. Nature 171, 426. doi: 10.1038/171426b0

Boehlert, G. M., and Mundy, B. C. (1994). Vertical and onshore-off-shore distributional patterns of tuna larvae in relation to physical habitat features. Mar. Ecol. Prog. Ser. 107, 1-13. doi: 10.3354/meps 107001

Boehlert, G. W., and Mundy, B. C. (1993). Ichthyoplankton assemblages at seamounts and oceanic islands. Bull. Mar. Sci. 53, 336-361.

Boehlert, G. W., Watson, W., and Sun, L. C. (1992). Horizontal and vertical distributions of larval fishes around and isolated island in the tropical Pacific. Deep-Sea Res. A 39, 439-366. doi: 10.1016/0198-0149(92)90082-5 of microplastic pollution in remote marine regions, including their interactions with meteo-oceanographic variables, living compartments and temporal trends to help assessing the role of microplastics in ecosystem functioning.

\section{AUTHOR CONTRIBUTIONS}

AL identify the fish larvae and the plastic debris, conducted the statistical analysis and write the manuscript. MB idealize the sampling design, conducted the samples in the Archipelago of Saint Peter and Saint-Paul, participate on the statistical analysis and write the manuscript. MC contributed with all information about plastic debris and in the English review of the text.

\section{FUNDING}

PROARquipelago program CNPq (Grant: 48.0040/2004-4) and by PNPD/CAPES/PPGO/UFPE.

\section{ACKNOWLEDGMENTS}

Authors acknowledge financial support from Fundação de Amparo à Ciência e Tecnologia do Estado de Pernambuco through scholarship (FACEPE/BFP-0130-1.08/15); Coordenação de Aperfeiçoamento de Pessoal de Nível Superior through scholarship (PNPD-UFPE/Oceanografia/CAPES); Conselho Nacional de Desenvolvimento Científico e Tecnológico through grant (PROARQUIPELAGO program CNPq-Proc.48.0040/ 2004-4; CNPq-Proc.405818/2012-2/COAGR/PESCA); Fundação de Apoio à Pesquisa do Estado de Pernambuco (FACEPE) through grant (FACEPE/APQ-0911-108/12); Comissão Interministerial para os Recursos do Mar (CIRM) for logistic support and fieldwork. MB and MC are CNPq Fellows.
Boerger, C. M., Lattin, G. L., Moore, S. L., and Moore, C. J. (2010). Plastic ingestion by planktivorous fishes in the North Pacific Central Gyre. Mar. Pollut. Bull. 60, 2275-2278. doi: 10.1016/j.marpolbul.2010.08.007

Bonecker, A. C. T., and Castro, M. S. (2006). Atlas de Larvas de Peixes da Região Central da Zona Econômica Exclusiva Brasileira. Série Livros/Documentos Técnicos 19. Museu Natcional, Universidade Federal do Rio de Janeiro, Rio de Janeiro.

Box, G. E. P., and Cox, D. R. (1964). An analysis of transformation. J. R. Stat. Soc. B 26, 211-252.

Chen, C.-L. (2015). "Regulation and management of marine litter," in Marine Anthropogenic Litter, eds M. Bergmann, L. Gutow, and M. Klages (Cham: Springer International Publishing), 395-428.

Chua, E. M., Shimeta, J., Nugegoda, D., Morrison, P. D., and Clarke, B. O. (2014). Assimilation of polybrominated diohenyl ethers from microplastics by the marine amphipoda, Allorchestes compressa. Environ. Sci. Technol. 48, 8127-8134. doi: 10.1021/es405717z

Cole, M., Lindeque, P., Halsband, C., and Galloway, T. S. (2011). Microplastic as contaminants in the marine environment: a review. Mar. Pollut. Bull. 62, 2588-2597. doi: 10.1016/j.marpolbul.2011.09.025

Cole, M., Lindeque, P. K., Fileman, E., Clark, J., Lewis, C., Halsband, C., et al. (2016). Microplastics alter the properties and sinking rates of zooplankton faecal pellets. Environ. Sci. Technol. 50, 3239-3246. doi: 10.1021/acs.est.5b05905

Collignon, A., Hecq, J., Galgani, F., Collard, F., and Goffart, A. (2014). Annual variation in neustonic micro- and meso-plastic particles and zooplankton in 
the Bay of Calvi (Mediterranean-Corsica). Mar. Pollut. Bull. 79, 293-298. doi: 10.1016/j.marpolbul.2013.11.023

Costa, M. F., and Barletta, M. (2015). Microplastics in coastal and marine environments of the western tropical and sub-tropical Atlantic Ocean. Environ. Sci. Process. Impacts 17, 1868-1879. doi: 10.1039/c5em00158g

Cowen, R. K., Paris, C. B., and Srinivasan, A. (2006). Scaling of connectivity in marine populations. Science 311, 522-527. doi: 10.1126/science.1122039

Dantas, D. V., Barletta, M., and Costa, M. F. (2012). The seasonal and spatial patterns of ingestion of polyfilament nylon fragments by estuarine drums (Sciaenidae). Eviron. Sci. Pollut. Res. 19, 600-606. doi: 10.1007/s11356-0110579-0

Diekmann, R., Nellen, W., and Piatkowski, U. (2006). A multivariate analysis of larval fish and paralarval cephalopod assemblages at Great Meteor Seamount. Deep Sea Res. I 53, 1635-1657. doi: 10.1016/j.dsr.2006.08.008

Dower, J. F., and Perry, R. I. (2001). High abundance of larval rockfish over Cobb Seamount, an isolated seamount in the Northeast Pecific. Fish. Oceanogr. 10, 268-274. doi: 10.1046/j.1365-2419.2001.00162.x

Doyle, M. J., Watson, W., Bowlin, N. M., and Sheavly, S. B. (2011). Plastic particles in coastal pelagic ecosystems of the Northeast Pacific ocean. Mar. Environ. Res. 71, 41-52. doi: 10.1016/j.marenvres.2010.10.001

Edwards, A. J., and Lubbock, R. (1983). The ecology of St Paul's Rocks. J. Biogeogr. 10, 65-72. doi: $10.2307 / 2844583$

Emery, A. R. (1972). Eddy formation from an oceanic island: ecological effects. Caribb. J. Sci. 12, 121-128.

Enders, K., Lenz, R., Stedmon, C. A., and Nielsen, T. G. (2015). Abundance, size and polymer composition of marine microplastics $\geq 10 \mu \mathrm{m}$ in the Atlantic Ocean and their modelled vertical distribution. Mar. Pollut. Bull. 100, 70-81. doi: 10.1016/j.marpolbul.2015.09.027

Eriksen, M., Lebreton, L. C. M., Carson, H. S., Thiel, M., Moore, C. J., Borerro, J. C., et al. (2014). Plastic pollution in the world's oceans: more than 5 trillion plastic pieces weighing over 250,000 Tons Afloat at Sea. PLoS ONE 9:e111913. doi: 10.1371 /journal.pone. 0111913

Fahay, M. P. (1983). Guide to the early stages of marine fishes occurring in the estern North Atlantic Ocean, Cape Hatteras to the southern Scotian Shelf. J. Northwest Atl. Fish. Sci. 4, 1-24. doi: 10.2960/J.v4.a1

Farrell, P., and Nelson, K. (2013). Trophic level transfer of microplastics: Mytillus edulis (L.) to Carcinus maenas (L.). Environ. Pollut. 177, 1-3. doi: 10.1016/j.envpol.2013.01.046

Ferreira, G. V. B., Barletta, M., Lima, A. R. A., Dantas, D. V., Justino, A. K. S., and Costa, M. F. (2016). Plastic debris contamination in the life cycle of Acoupa weakfish (Cynoscion acoupa) in a tropical estuary. ICES J. Mar. Sci. fsw108. doi: 10.1093/icesjms/fsw108

Fowler, A. M., Leis, J. M., and Suthers, I. M. (2008). Onshore-offshore distribution and abundance of tune larvae (Pisces: Scombridae: Thunnini) in nearshore-reef waters of the Coral Sea. Fish. Bull. 106, 405-416. Available online at: http://hdl. handle.net/10453/15016

Frias, J. P. G. L., Sobral, P., and Ferreira, A. M. (2010). Organic pollutants in microplastics from two beaches of the Portuguese coast. Mar. Pollut. Bull. 60, 1988-1992. doi: 10.1016/j.marpolbul.2010.07.030

Froese, R., and Pauly, D. (eds.). (2015). FishBase. World Wide Web Electronic Publication. Available online at: http://www.fishbase.org (Accessed July, 2015)

Guebert-Bartholo, F. M., Barletta, M., Costa, M. F., Lucena, L. R., and Pereira da Silva, C. (2011). Fishery and the use of space in a tropical semi-arid estuarine region of Northeast Brazil: subsistence and overexploitation. J. Coast. Res. SI $64,398-402$.

Hamner, W. M., and Hauri, K. R. (1981). Effects of island mass: water flow and plankton pattern around a reef in the Great Barrier Reef Lagoon, Australia. Limnol. Oceanogr. 26, 1084-1103. doi: 10.4319/lo.1981.26.6.1084

Ivar do Sul, J. A., Costa, M. F., Barletta, M., and Cysneiros, F. J. A. (2013). Pelagic microplastics around an archipelago of the Equatorial Atlantic. Mar. Pollut. Bull. 75, 305-309. doi: 10.1016/j.marpolbul.2013.07.040

Ivar do Sul, J. A., Costa, M. F., and Fillmann, G. (2014). Microplastics in the pelagic environment around oceanic islands of the Western Tropical Atlantic Ocean. Water Air Soil Pollut. 225, 1-13. doi: 10.1007/s11270-014-2004-z

Joo, H., Son, S., Park, J.-W., Kang, J. J., Jeong, J.-Y., Lee, C. I., et al. (2016). LongTerm pattern of primary productivity in the east/japan sea based on ocean color data derived from MODIS-Aqua. Remote Sens. 8:25. doi: 10.3390/rs8010025
Leis, J. M., and Miller, J. M. (1976). Offshore distributional patterns of Hawaiian fish larvae. Mar. Biol. 36, 359-367. doi: 10.1007/BF00389198

Leis, J. M., and Trnski, T. (1989). The Larvae of Indo-Pacific Shorefishes. Kensington: New South Wales University Press.

Leis, J. M., Trnski, T., Harmelin-Vivien, M., Renon, J.-P., Dufour, V., El Moudni, M., et al. (1991). High concentration of tuna larvae (Pisces: Scombridae) in near-reef waters of French Polynesia (Society and Tuamotu Islands). Bull. Mar. Sci. 48, 150-158.

Lima, A. R. A., Barletta, M., and Costa, M. F. (2015). Seasonal distribution and interactions between plankton and microplastics in a tropical estuary. Estuar. Coast. Shelf Sci. 165, 213-225. doi: 10.1016/j.ecss.2015.05.018

Lima, A. R. A., Barletta, M., Costa, M. F., Ramos, J. A. A., Dantas, D. V., Justino, A. K. S., et al. (2016). Changes in the composition of ichthyoplankton assemblage and plastic debris in mangrove creeks relative to moon phases. J. Fish Biol. 89, 619-640. doi: 10.1111/jfb.12838

Lima, A. R. A., Costa, M. F., and Barletta, M. (2014). Distribution patterns of microplastic within the plankton of a tropical estuary. Environ. Res. 132, 146-155. doi: 10.1016/j.envres.2014.03.031

Long, M., Moriceau, B., Gallinari, M., Lambert, C., Huvet, A., Raffray, J., et al. (2015). Interactions between microplastics and phytoplankton aggregates: Impact on their respective fates. Mar. Chem. 175, 39-46. doi: 10.1016/j.marchem.2015.04.003

Lönnstedt, O. M., and Eklöv, P. (2016). Environmentally relevant concentrations of microplastic particles influence larval fish ecology. Science 352, 1213-1216. doi: $10.1126 /$ science.aad 8828

Luiz, O. J., and Edwards, A. J. (2011). Extinction of a shark population in the Archipelago of Saint Paul's Rocks (Equatorial Atlantic) inferred from the historical record. Biol. Conserv. 144, 2873-2881. doi: 10.1016/j.biocon.2011. 08.004

Lumpkin, R., and Garzoli, S. L. (2005). Near-surface circulation in the Tropical Atlantic Ocean. Deep-Sea Res. I 52, 495-518. doi: 10.1016/j.dsr.2004.09.001

Lusher, A. (2015). "Microplastics in the marine environment: distribution, interactions and effects," in Marine Anthropogenic Litter, eds M. Bergmann, L. Gutow, and M. Klages (Cham: Springer International Publishing), 245-307.

Lusher, A. L., Burke, A., O'Connor, I., and Officer, R. (2014). Microplastic pollution in the Northeast Atlantic Ocean: validated and opportunistic sampling. Mar. Pollut. Bull. 88, 325-333. doi: 10.1016/j.marpolbul.2014.08.023

Lusher, A. L., McHugh, M., and Thompson, R. C. (2013). Occurrence of microplastics in the gastrointestinal tract of pelagic and demersal fish from the English Channel. Mar. Pollut. Bull. 67, 94-99. doi: 10.1016/j.marpolbul.2012. 11.028

Lusher, A. L., Tirelli, V., O’Connor, I., and Officer, R. (2015). Microplastics in Arctic polar waters: the first reported values of particles in surface and sub-surface samples. Sci. Rep. 5:14947. doi: 10.1038/srep14947

Macedo-Soares, L. C. P., Freire, A. S., Koettker, A. G., Menezes, B. S., Fernández, D. B., and Brandão, M. C. (2009). "Zooplâncton", in O Arquipélago de São Pedro e São Paulo: 10 anos de Estação Científica, ed F. H. V. Hazin (Brasília: SECIRM), 128-137.

Macedo-Soares, L. C. P., Freire, A. S., and Muelbert, J. H. (2012). Small-scale spatial and temporal variability of larval fish assemblages at an isolated oceanic island. Mar. Ecol. Prog. Ser. 444, 207-222. doi: 10.3354/meps09436

Maximenko, N., Hafner, J., and Niiler, P. (2012). Pathways of marine debris from trajectories of Lagrangian drifters. Mar. Pollut. Bull. 65, 51-62. doi: 10.1016/j.marpolbul.2011.04.016

Melo, P. A. M. C., Diaz, X. F. G., Macedo, S. J. M., and Neumann-Leitão, S. (2012). Diurnal and spatial variation of the mesozooplankton community in the Saint Peter and Saint Paul Archipelago, Equatorial Atlantic. Mar. Biodivers. Rec. 5, 1-14. doi: $10.1017 /$ S1755267212001054

Miller, J. M. (1979). Nearshore abundance of tuna (Pisces: Scombridae) larvae in the Hawaiian Island. Bull. Mar. Sci. 29, 19-26.

Moore, C. J. (2008). Synthetic polymers in the marine environment: a rapidly increasing, long-term threat. Environ. Res. 108, 131-139. doi: 10.1016/j.envres.2008.07.025

Moore, C. J., Moore, S. L., Weisberg, S. B., Lattin, G. L., and Zellers, A. F. (2002). A comparison of neustonic plastic and zooplankton abundance in southern California's coastal waters. Mar. Pollut. Bull. 44, 1035-1038. doi: 10.1016/S0025-326X(02)00150-9 
Morato, T., Hoyle, S. D., Allain, V., and Nicol, S. J. (2010). Seamount are hotspots of pelagic biodiversity in the open ocean. Proc. Natl. Acad. Sci. U.S.A. 107, 9707-9711. doi: 10.1073/pnas.0910290107

Moser, H. G. (ed.). (1996). The Early Stages of Fishes in the California Corrent Region. CalCOFI Atlas 33. Lawrence, KS: Allen Press.

Moyano, M., Rodrígues, J. M., Benítez-Barrios, V. M., and Hernández-León, S. (2014). Larval fish distribution and retention in the Canary Current system during the waek upwelling season. Fish. Oceanogr. 23, 191-209. doi: 10.1111/fog. 12055

Neves, D., Sobral, P., Ferreira, J. L., and Pereira, T. (2015). Ingestion of microplastics by commercial fish off the Portuguese coast. Mar. Pollut. Bull. 101, 119-126. doi: 10.1016/j.marpolbul.2015.11.008

Nonaka, R. H., Matsuura, Y., and Suzuki, K. (2000). Seasonal variation in larval fish assemblages in relation to oceanographic conditions in the Abrolhos Bank region off eastern Brazil. Fish. Bull. 98, 767-784.

Palmer, M. W. (1993). Putting things in even better order: the advantages of canonical correspondence analysis. Ecology 74, 2215-2230. doi: $10.2307 / 1939575$

Panti, C., Giannetti, M., Baini, M., Rubegni, F., Minutoli, R., and Fossi, M. C. (2015). Occurrence, relative abundance and spatial distribution of microplastics and zooplankton NW of Sardinia in the Pelagos Sanctuary Protected Area, Mediterranean Sea. Environ. Chem. 12, 618-626. doi: 10.1071/EN14234

Pearce, A. F., and Hutchins, J. B. (2009). Oceanic process and the recruitment of tropical fish at Rottnest Island (Western Australia). J. R. Soc. West. Aust. 92, 179-195.

Possatto, F. E., Barletta, M., Costa, M. F., Ivar do Sul, J. A., and Dantas, D. V. (2011). Plastic debris ingestion by marine catfishes: an unexpected fisheries impact. Mar. Pollut. Bull. 62, 1098-1102. doi: 10.1016/j.marpolbul.2011.01.036

Quinn, G. R., and Keough, M. J. (2002). Experimental Design and Data Analysis for Biologists. Cambridge: Cambridge University Press.

Ramos, J. A. A., Barletta, M., and Costa, M. F. (2012). Ingestion of nylon threads by Gerreidae while using a tropical estuary as foraging grounds. Aquat. Biol. 17, 29-34. doi: 10.3354/ab00461

Richards, W. J. (2006). Early Stages of Atlantic Fishes. An Identification Guide for the Western Central North Atlantic, Vol. 2. Boca Raton, FL: CRC Press; Taylor \& Francis Group.

Rochman, C. M., Hoh, E., Kurobe, T., and The, S. J. (2013). Ingested plastic transfers hazardous chemicals to fish and induces hepatic stress. Sci. Rep. 3:3263. doi: $10.1038 /$ srep 03263

Rummel, C. D., Löder, M. G. J., Fricke, N. F., Lang, T., Griebeler, E., Janke, M., et al. (2016). Plastic ingestion by pelagic and demersal fish from the North Sea and Baltic Sea. Mar. Pollut. Bull. 102, 134-141. doi: 10.1016/j.marpolbul.2015.11.043

Sá, L. C., Luís, L. G., and Guilhermino, L. (2015). Effects of microplastics on juvenile of the common goby (Pomatoschistus microps): confusion with prey, reduction of the predatory performance and efficiency, and possible influence of developmental conditions. Environ. Pollut. 196, 369-362. doi: 10.1016/j.envpol.2014.10.026

Sabatés, A., Zabala, M., and García-Rubies, A. (2003). Larval fish communities in the medes island marine reserve (northe-west maditerranean). J. Plankton Res. 25, 1035-1046. doi: 10.1093/plankt/25.9.1035

Sale, P. F. (1970). Distribution of larval Acanthuridae off Hawaii. Copeia 1970, 765-766. doi: 10.2307/1442323

Setälä, O., Fleming-Lehtinen, V., and Lehtiniemi, M. (2014). Ingestion and transfer of microplastics in the planktonic food web. Environ. Pollut. 185, 77-83. doi: 10.1016/j.envpol.2013.10.013

Setälä, O., Norkko, J., and Lehtiniemi, M. (2016). Feeding type affects microplastic ingestion in a coastal invertebrate community. Mar. Pollut. Bull. 102, 95-101. doi: 10.1016/j.marpolbul.2015.11.053

Sichel, S. E., Esperança, S., Motoki, A., and Maia, M. (2008). Geophysical and geochemical evidence for cold upper mantle beneath the equatorial Atlantic Ocean. Rev. Bras. Geofísica 26, 69-86. doi: 10.1590/S0102-261X2008000100006

Soares, J., Oliveira, A. P., Skielka, U. T., and Servain, J. (2009). "O ar.," in $O$ Arquipéligo de São Pedro e São Paulo: 10 Anos de Estação Científica, ed F. H. V. Hazin (Brasília: SECIRM), 38-44.
Stramma, L., and Schott, F. (1999). The mean flow field of the tropical Atlantic Ocean. Deep-Sea Res. II 46, 279-303. doi: 10.1016/S0967-0645(98)00109-X

Swearer, S. E., Casselle, J. E., Lea, D. W., and Warner, R. R. (1999). Larval retention and recruitment in an island population of a coral-reef fish. Nature 402, 799-802. doi: $10.1038 / 45533$

Tanaka, K., Takada, H., Yamashita, R., Mizukawa, K., and Fukuwaka, M. (2013). Accumulation of plastic-derived chemicals in tissues of seabirds ingesting marine plastics. Mar. Pollut. Bull. 69, 219-222. doi: 10.1016/j.marpolbul.2012.12.010

ter Braak, C. J. F. (1986). Canonical correspondence analysis: a new eigenvector techinique for multivariate direct gradient analysis. Ecology 67, 1167-1179. doi: $10.2307 / 1938672$

ter Braak, C. J. F., and Smilauer, P. (2002). CANOCO Reference Manual and CanoDraw for Windows User's Guide: Software for Canonical Community Ordination (version 4.5) - Microcomputer Power. Ithaca, NY. Available online at: https://www.researchgate.net/publication/239446793_Canoco_ reference_manual_and_CanoDraw_for_Windows_user\% $27 \% 27 \mathrm{~s}$ _guide_softw are for_canonical_community_ord

Thompson, R. C., Swan, S. H., Moore, C. J., and vom Saal, F. S. (2009). Our plastic age. Philos. Trans. R. Soc. B Biol. Sci. 364, 1973-1196. doi: 10.1098/rstb.2009.0054

Travassos, P., Hazin, F. H. V., Zagaglia, J. R., Advincula, R., and Schober, J. (1999). Thermohaline structure around seamounts and islands off north-eastern Brazil. Arch. Fish. Mar. Res. 47, 211-222.

Turner, A. (2010). Marine pollution from antifouling paint particles. Mar. Pollut. Bull. 60, 159-171. doi: 10.1016/j.marpolbul.2009.12.004

Vaske, T. Jr., Lessa, R. P., Nóbrega, M., Montealegre-Quijano, S., Marcante Santana, F., Bezerra, J. L., et al. (2005). A checklist of fishes from Saint Peter and Saint Paul Archipelago, Brazil. J. Appl. Ichthyol. 21, 77-79. doi: 10.1111/j.1439-0426.2004.00600.x

Victor, B. C. (1987). Growth, dispersal, and identification of planktonic labrid and pomancentrid reef-fish larvae in the eastern Pacific Ocean. Mar. Biol. 95, 145-152. doi: 10.1007/BF00447496

Vigliola, L., Harmelin-Vivien, M. L., Biagi, F., Galzin, R., García-Rubies, A., Harmelin, J. G., et al. (1998). Spatial and temporal patterns of settlement among Diplodus sparid fishes in the northwestern Mediterranean. Mar. Ecol. Prog. Ser. 168, 45-56. doi: 10.3354/meps168045

Wardrop, P., Shimeta, J., Nugegoda, D., Morrison, P. D., Miranda, A., Tang, M., et al. (2016). Chemical pollutants sorbed to ingested microbeads from personal care products accumulate in fish. Environ. Sci. Technol. 50, 4037-4044. doi: 10.1021/acs.est.5b06280

Watters, D. L., Yoklavich, M. M., Love, M. S., and Schroeder, D. M. (2010). Assessing marine debris in deep seafloor habitats off California. Mar. Pollut. Bull. 60, 131-138. doi: 10.1016/j.marpolbul.2009.08.019

Wolanski, E., and Hamner, W. M. (1988). Topographically controlled fronts in the ocean and their biological influence. Science 241, 177-181. doi: 10.1126/science.241.4862.177

Wright, S. L., Thompson, R. C., and Galloway, T. S. (2013). The physical impacts of microplastics on marine organisms: a review. Environ. Pollut. 178, 483-492. doi: 10.1016/j.envpol.2013.02.031

Yu, X., Peng, J., Wang, J., Wang, K., and Bao, S. (2016). Occurrence of microplastics in the beach sand of the Chinese inner sea: the Bohai Sea. Environ. Pollut. 214, 722-730. doi: 10.1016/j.envpol.2016.04.080

Zar, J. H. (1996). Biostatistical Analysis. Upper Sanddle River, NJ: Prentice Hall.

Conflict of Interest Statement: The authors declare that the research was conducted in the absence of any commercial or financial relationships that could be construed as a potential conflict of interest.

Copyright $\odot 2016$ Lima, Barletta and Costa. This is an open-access article distributed under the terms of the Creative Commons Attribution License (CC BY). The use, distribution or reproduction in other forums is permitted, provided the original author(s) or licensor are credited and that the original publication in this journal is cited, in accordance with accepted academic practice. No use, distribution or reproduction is permitted which does not comply with these terms. 